\title{
Selective hydrogenolysis of glycerol to propylene glycol on hydroxycarbonate-derived $\mathrm{Cu}-\mathrm{ZnO}-\mathrm{Al}_{2} \mathrm{O}_{3}$ catalysts
}

\author{
Shuai Wang, Haichao Liu* \\ Beijing National Laboratory for Molecular Sciences, State Key Laboratory for Structural Chemistry of Unstable and Stable Species, College of Chemistry \\ and Molecular Engineering, Peking University, Beijing 100871, China
}

\section{A R T I C L E I N F O}

Article history:

Received 20 March 2014

Accepted 27 March 2014

Published 20 May 2014

\section{Keywords:}

Glycerol

Selective hydrogenolysis

Propylene glycol

Copper

Zinc oxide

Alumina

Hydroxycarbonate precursor

Structure-activity relationship Stability

\begin{abstract}
A B S T R A C T
Three $\mathrm{Cu}-\mathrm{ZnO}-\mathrm{Al}_{2} \mathrm{O}_{3}$ catalysts with similar compositions were prepared by homogeneous coprecipitation (CZA-HP), deposition-precipitation (CZA-DP), and conventional coprecipitation (CZA-CP). A $\mathrm{Cu}-\mathrm{ZnO}$ catalyst was also prepared by homogeneous coprecipitation (CZ-HP) for reference. X-ray diffraction results showed that the degree of mixing of $\mathrm{Cu}^{2+}, \mathrm{Zn}^{2+}$, and $\mathrm{Al}^{3+}$ ions in the $\mathrm{Cu}-\mathrm{Zn}$ - $\mathrm{Al}$ hydroxycarbonate precursor followed the order of CZA-DP $<$ CZA-HP $<$ CZA-CP. A more homogeneous aluminum distribution and intimate contact between $\mathrm{Al}_{2} \mathrm{O}_{3}$ and $\mathrm{ZnO}$ led to smaller $\mathrm{CuO}$ and $\mathrm{ZnO}$ crystallites in the $\mathrm{CuO}-\mathrm{ZnO}-\mathrm{Al}_{2} \mathrm{O}_{3}$ composite oxides, and consequently smaller $\mathrm{Cu}$ and $\mathrm{ZnO}$ crystallites in the final $\mathrm{Cu}-\mathrm{ZnO}-\mathrm{Al}_{2} \mathrm{O}_{3}$ catalysts. However, the intimate $\mathrm{ZnO}^{-} \mathrm{Al}_{2} \mathrm{O}_{3}$ contact hindered the interaction between $\mathrm{Cu}$ and $\mathrm{ZnO}$ in the $\mathrm{Cu}-\mathrm{ZnO}-\mathrm{Al}_{2} \mathrm{O}_{3}$ catalysts. As a result of these effects of $\mathrm{Al}_{2} \mathrm{O}_{3}$, for the samples other than CZA-CP, the $\mathrm{Cu}$ particles on CZA-HP showed the highest redox activity, which was characterized by $\mathrm{N}_{2} \mathrm{O}$ chemisorption $-\mathrm{H}_{2}$ temperature-programmed reduction. These catalysts catalyzed glycerol hydrogenolysis to propylene glycol with high selectivities above $90 \%$ at $30 \%$ glycerol conversion ( $473 \mathrm{~K}$ and $6.0 \mathrm{MPa} \mathrm{H}_{2}$ ). Their activities normalized per exposed surface $\mathrm{Cu}$ atom to give turnover frequencies increased in the order CZA-DP $<$ CZA-CP $<$ CZ-HP $<$ CZA-HP, which was the order of the redox ability of the $\mathrm{Cu}$ particles. The addition of alumina increased the stability of $\mathrm{Cu}-\mathrm{ZnO}$ catalysts. After six cycles ( $6 \mathrm{~h}$ per run), the activity of CZ-HP decreased by $45 \%$ accompanied by an increase of $\mathrm{Cu}$ crystallite size from 13.2 to $45.2 \mathrm{~nm}$, while that of CZA-HP decreased only by $10 \%$ with an increase of the $\mathrm{Cu}$ crystallite size from 8.3 to $19.0 \mathrm{~nm}$. These results demonstrated the promoting effects of $\mathrm{Al}_{2} \mathrm{O}_{3}$ on the activity and stability of $\mathrm{Cu}-\mathrm{ZnO}$ catalysts derived from the hydroxycarbonates.
\end{abstract}

(C) 2014, Dalian Institute of Chemical Physics, Chinese Academy of Sciences. Published by Elsevier B.V. All rights reserved.

\section{Introduction}

Glycerol hydrogenolysis to propylene glycol has been intensively studied in the past decade as an alternative route for the efficient utilization of surplus glycerol, an inevitable byproduct of biodiesel processes [1-5]. Cu-based catalysts, such as $\mathrm{Cu}-\mathrm{ZnO}$ [6], $\mathrm{Cu}-\mathrm{SiO}_{2}[7,8], \mathrm{Cu} / \mathrm{Al}_{2} \mathrm{O}_{3}$ [9], $\mathrm{Cu}-\mathrm{ZnO}-\mathrm{Al}_{2} \mathrm{O}_{3}[10,11]$, and
$\mathrm{Cu} / \mathrm{MgO}-\mathrm{Al}_{2} \mathrm{O}_{3}$ [12], exhibit high selectivity for propylene glycol (above 90\%) even at high glycerol conversions (> 75\%). In contrast, catalysts containing Group VIII metals, such as $\mathrm{Ru}, \mathrm{Rh}$, $\mathrm{Pt}$, and $\mathrm{Ni}$, tend to cleave the $\mathrm{C}-\mathrm{C}$ bonds of glycerol leading to the formation of ethylene glycol and even methane [13-16]. Despite the superior selectivity of Cu-based catalysts, they possess inferior intrinsic activity and especially hydrothermal

\footnotetext{
* Corresponding author. Tel/Fax: +86-10-62754031; E-mail: hcliu@pku.edu.cn

This work was supported by the National Basic Research Program of China (973 Program, 2011CB201400, 2011CB808700) and the National Natural Science Foundation of China (21173008, 21373019, 51121091). DOI: 10.1016/S1872-2067(14)60094-2 | http://www.sciencedirect.com/science/journal/18722067 | Chin. J. Catal., Vol. 35, No. 5, May 2014
} 
stability compared with the Group VIII metals [1,2]. Therefore, the design of novel $\mathrm{Cu}$-based catalysts is focused on how to improve the activity of $\mathrm{Cu}$ and its stability under the hydrothermal reaction conditions of glycerol hydrogenolysis [17-20]. Small $\mathrm{Cu}$ particles and a strong $\mathrm{Cu}$-support interaction can promote the redox ability of the $\mathrm{Cu}$ particles, and consequently their hydrogenolysis activity, according to the proposed mechanism involving glycerol dehydrogenation to glyceraldehyde on the metal surface as the kinetically relevant step $[6,13]$. The use of a hydrothermally stable support can prevent the agglomeration of the $\mathrm{Cu}$ particles during the hydrogenolysis in the aqueous phase [21]. For instance, Bienholz et al. [22] found that the introduction of $\mathrm{Ga}_{2} \mathrm{O}_{3}$ into $\mathrm{Cu}-\mathrm{ZnO}$ catalysts remarkably enhanced the stability of the $\mathrm{Cu}$ particles, which showed essentially no loss of activity (less than 10\%) after four reaction cycles with a total reaction time of $20 \mathrm{~h}$ at $473 \mathrm{~K}$ and $5.0 \mathrm{MPa} \mathrm{H}_{2}$.

Our previous studies have shown that the homogeneous mixing of $\mathrm{Cu}^{2+}$ and $\mathrm{Zn}^{2+}$ ions in the $\mathrm{Cu}-\mathrm{Zn}$ hydroxycarbonate prepared by homogeneous coprecipitation using urea hydrolysis favored the formation of small $\mathrm{Cu}$ particles with a strong $\mathrm{Cu}-\mathrm{ZnO}$ interaction in the resulting $\mathrm{Cu}-\mathrm{ZnO}$ catalyst, and this catalyst gave good activity in glycerol selective hydrogenolysis to propylene glycol $[6,23]$. In this work, $\mathrm{Al}_{2} \mathrm{O}_{3}$ was introduced into the $\mathrm{Cu}-\mathrm{ZnO}$ catalysts in order to increase the activity and stability of the $\mathrm{Cu}$ particles, based on the consideration of the much larger surface area and better thermal stability of $\mathrm{Al}_{2} \mathrm{O}_{3}$ compared with $\mathrm{ZnO}$ [24]. The promoting effects of $\mathrm{Al}_{2} \mathrm{O}_{3}$ were elucidated from a comparison of three $\mathrm{Cu}-\mathrm{ZnO}-\mathrm{Al}_{2} \mathrm{O}_{3}$ catalysts prepared by different coprecipitation methods. A correlation between the structure of the $\mathrm{Cu}-\mathrm{ZnO}-\mathrm{Al}_{2} \mathrm{O}_{3}$ catalysts and their hydroxycarbonate phase was also revealed.

\section{Experimental}

\subsection{Preparation of the catalysts}

Three Cu-Zn-Al hydroxycarbonate precursors with a Cu:Zn: Al molar ratio of 40:40:20 were prepared by homogeneous coprecipitation [25], deposition-precipitation [8], and conventional coprecipitation methods [26]. $\mathrm{Cu}\left(\mathrm{NO}_{3}\right)_{2} \cdot 3 \mathrm{H}_{2} \mathrm{O}, \mathrm{Zn}\left(\mathrm{NO}_{3}\right)_{2}$. $3 \mathrm{H}_{2} \mathrm{O}$, and $\mathrm{Al}\left(\mathrm{NO}_{3}\right)_{3} \cdot 9 \mathrm{H}_{2} \mathrm{O}$ were the metal sources (Beijing Chemicals, AR grade). For the homogeneous coprecipitation method, the metal nitrates with the desired Cu:Zn:Al molar ratio and urea (Beijing Chemicals, AR grade) were dissolved together in $100 \mathrm{~mL} \mathrm{H} \mathrm{H}_{2} \mathrm{O}$. The total concentration of the cations was $0.30 \mathrm{~mol} / \mathrm{L}$, while the urea concentration was $3.0 \mathrm{~mol} / \mathrm{L}$. The aqueous solution was heated to $373 \mathrm{~K}$ and maintained at $373 \mathrm{~K}$ for $3 \mathrm{~h}$ to form the $\mathrm{Cu}-\mathrm{Zn}$-Al hydroxycarbonate. $\mathrm{A} \mathrm{Cu}-\mathrm{Zn}$ hydroxycarbonate with a $\mathrm{Cu}: \mathrm{Zn}$ molar ratio of 50:50 was also prepared by the same method for reference. For the deposition-precipitation method, the procedure was similar to the homogeneous coprecipitation method except that $\mathrm{Al}\left(\mathrm{NO}_{3}\right)_{3}$. $9 \mathrm{H}_{2} \mathrm{O}$ was replaced by an $\mathrm{Al}(\mathrm{OH})_{3}$ gel. The $\mathrm{Al}(\mathrm{OH})_{3}$ gel was prepared using the same homogeneous coprecipitation method via urea hydrolysis. For the conventional coprecipitation method, a solution of the three metal nitrates and a solution containing $\mathrm{NaOH}$ (0.34 mol/L, Beijing Chemicals, AR grade) and
$\mathrm{Na}_{2} \mathrm{CO}_{3}$ (0.060 mol/L, Beijing Chemicals, AR grade) were placed simultaneously into $50 \mathrm{~mL} \mathrm{H}_{2} \mathrm{O}$ under vigorous stirring at room temperature. The resulting precipitate was aged overnight in the mother liquor. The $\mathrm{pH}$ value was kept at 9-10 during the solution addition and aging. The precipitate from each of the above three methods was filtered and washed with deionized water until the filtrate was neutral. The precipitate was subsequently heated in ambient air at $383 \mathrm{~K}$ overnight and at $673 \mathrm{~K}$ for $4 \mathrm{~h}$. The $\mathrm{Cu}-\mathrm{ZnO}$ and $\mathrm{Cu}-\mathrm{ZnO}-\mathrm{Al}_{2} \mathrm{O}_{3}$ catalysts were obtained after a treatment in $20 \% \mathrm{H}_{2} / \mathrm{N}_{2}$ flow (Beijing Huayuan, certified mixture) at $623 \mathrm{~K}$ for $4 \mathrm{~h}$. Inductively coupled plasma (Vario EL) analysis showed that the average $\mathrm{Cu}: \mathrm{Zn}$ molar ratio of the $\mathrm{Cu}-\mathrm{ZnO}$ catalyst prepared from the homogeneous coprecipitation method was 51:49. The Cu:Zn:Al molar ratios in the $\mathrm{Cu}-\mathrm{ZnO}-\mathrm{Al}_{2} \mathrm{O}_{3}$ catalysts prepared from the homogeneous coprecipitation, deposition-precipitation, and conventional coprecipitation methods were 39:39:22, 39:42:19, and 40:39:21, respectively. The compositions of these $\mathrm{Cu}$-based catalysts were all close to their nominal values.

\subsection{Characterization of the catalysts}

X-ray diffraction $(\mathrm{XRD})$ measurements $\left(2 \theta=10^{\circ}-80^{\circ}\right)$ were carried out on a Rigaku D/MAX-2400 diffractometer using $\mathrm{Cu}$ $K_{\alpha 1}$ radiation $(\lambda=0.15406 \mathrm{~nm})$ operated at $40 \mathrm{kV}$ and $100 \mathrm{~mA}$. The Scherrer equation was applied to calculate the crystallite sizes of $\mathrm{ZnO}, \mathrm{CuO}$, and $\mathrm{Cu}$. $\mathrm{N}_{2}$ physisorption was performed on an ASAP 2010 analyzer (Micromeritics) after the sample was evacuated $(<2.66 \mathrm{~Pa})$ at $393 \mathrm{~K}$ for $4 \mathrm{~h}$. The specific surface area was evaluated from the adsorption data using the BET method. $\mathrm{Cu}$ dispersion was obtained using a dissociative $\mathrm{N}_{2} \mathrm{O}$ adsorption- $\mathrm{H}_{2}$ temperature-programmed reduction ( $\mathrm{H}_{2}$-TPR) method on a flow unit (TP5000, Tianjin Xianquan) [6]. A fresh Cu catalyst was exposed to a $5 \% \mathrm{~N}_{2} \mathrm{O} / \mathrm{He}$ mixture $(40 \mathrm{~mL} / \mathrm{min}$, Beijing Huayuan) at $323 \mathrm{~K}$ for $0.5 \mathrm{~h}$ to oxidize the surface $\mathrm{Cu}$ sites to $\mathrm{Cu}_{2} \mathrm{O}$. The resulting sample was cooled to room temperature in He flow (40 mL/min, Beijing Huayuan), and then $\mathrm{H}_{2}$-TPR was performed in $5 \% \mathrm{H}_{2} / \mathrm{N}_{2}$ flow ( $40 \mathrm{~mL} / \mathrm{min}$, Beijing Huayuan). $\mathrm{H}_{2}$ consumption was quantitatively measured by a thermal conductivity detector.

\subsection{Glycerol hydrogenolysis reaction}

10 wt\% glycerol (50 g, AR, Beijing Chemical) aqueous solution and a weighted amount of $\mathrm{Cu}$ catalyst were placed in a teflon-lined stainless steel autoclave $(100 \mathrm{~mL})$. The glycerol hydrogenolysis reaction was run at $6.0 \mathrm{MPa}_{2}$ and $473 \mathrm{~K}$ with a stirring speed of $800 \mathrm{r} / \mathrm{min}$. The used catalyst and liquid product were separated by filtration after the reaction. A gas chromatograph (Agilent 7890A GC) with a capillary column (AT-Aquawax: $30 \mathrm{~m} \times 0.25 \mathrm{~mm} \times 0.25 \mu \mathrm{m}$ ) connected to a flame ionization detector was used to analyze the liquid product. Volatile compounds such as methanol and 1-propanol were quantified with an internal standard of 1-butanol, while high boiling point compounds such as glycerol, propylene glycol, and ethylene glycol were quantified with an internal standard of 1,4-butanediol. The gas product, which was mainly methane 
and $\mathrm{CO}_{2}$, was analyzed using a Porapak $\mathrm{Q}$ column and a thermal conductivity detector. Good carbon balances were achieved in the product analysis $(100 \% \pm 5 \%)$. As with our previous reports $[6,13,20]$, the activity was described by the molar glycerol conversion per mole of exposed $\mathrm{Cu}$ atoms (obtained from the measurement of $\mathrm{Cu}$ dispersion) and product selectivities were calculated on the carbon basis.

\section{Results and discussion}

\subsection{Synthesis of the Cu-Zn-Al hydroxycarbonate precursor}

The catalytic activity of $\mathrm{Cu}-\mathrm{ZnO} 0$-based catalysts synthesized by coprecipitation methods is closely related to their hydroxycarbonate precursor [27-29]. For instance, aurichalcite $\left(\mathrm{Cu}_{x} \mathrm{Zn}_{1-x}\right)_{5}(\mathrm{OH})_{6}\left(\mathrm{CO}_{3}\right)_{2}$ and rosasite $\left(\mathrm{Cu}_{x} \mathrm{Zn}_{1-x}\right)_{2}(\mathrm{OH})_{2} \mathrm{CO}_{3}(0<x$ $<1$ ) are both made of $\mathrm{MO}_{6}$ octahedral units $(\mathrm{M}=\mathrm{Cu}$ and $\mathrm{Zn})$, with the $\mathrm{CuO}_{6}$ and $\mathrm{ZnO}_{6}$ units being distributed more homogeneously and intimately in the former crystalline phase [30]. In line with their structural difference, $\mathrm{Cu}-\mathrm{ZnO}$ catalysts derived from the aurichalcite precursor showed smaller $\mathrm{Cu}$ cluster sizes and a stronger interaction between $\mathrm{Cu}$ and $\mathrm{ZnO}$ than those derived from the rosasite precursor [27]. It has been consistently found that aurichalcite is a superior $\mathrm{Cu}-\mathrm{ZnO}$ precursor compared with rosasite in glycerol hydrogenolysis [6]. By following the same rule, the effects of aluminum in the ternary $\mathrm{Cu}-\mathrm{ZnO}-\mathrm{Al}_{2} \mathrm{O}_{3}$ catalysts can be traced back to the connections between the $\mathrm{CuO}_{6}, \mathrm{ZnO}_{6}$, and $\mathrm{AlO}_{6}$ octahedral units in the hydroxycarbonate precursors [28,31].

Homogeneous coprecipitation by urea hydrolysis was applied here to prepare a $\mathrm{Cu}-\mathrm{ZnO}-\mathrm{Al}_{2} \mathrm{O}_{3}$ catalyst with a $\mathrm{Cu}: \mathrm{Zn}: \mathrm{Al}$ molar ratio of 40:40:20. A Cu-ZnO catalyst $(\mathrm{Cu}: \mathrm{Zn}=50: 50$ in molar units) was also prepared using the same method for comparison. These were labeled as CZA-HP and CZ-HP in this work, respectively. Figure 1 shows the XRD patterns for the hydroxycarbonate precursor of the two catalysts. The hy-

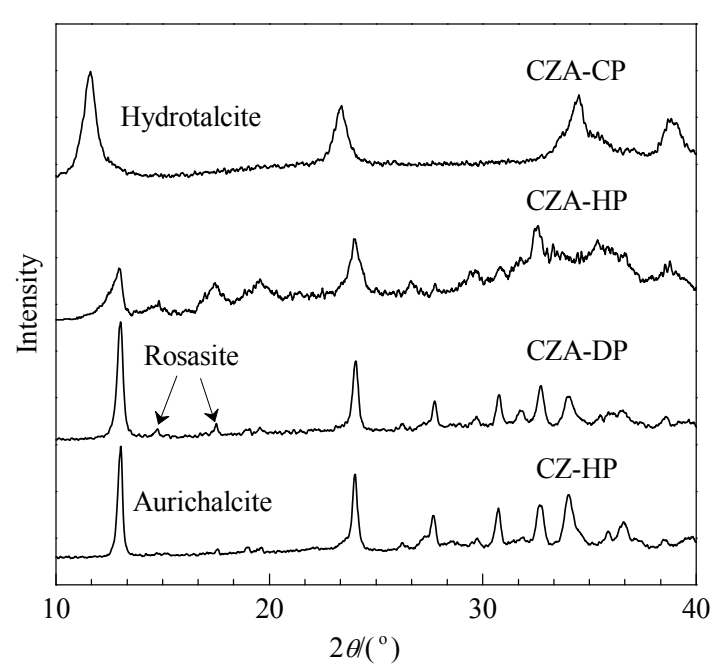

Fig. 1. XRD patterns of the $\mathrm{Cu}-\mathrm{Zn}$-Al hydroxycarbonate precursors prepared via homogeneous coprecipitation (CZA-HP), deposition-precipitation (CZA-DP), and conventional coprecipitation (CZA-CP), and for comparison a pure aurichalcite $\mathrm{Cu}-\mathrm{Zn}$ hydroxycarbonate precursor prepared via homogeneous coprecipitation (CZ-HP). droxycarbonate precursor of CZ-HP consists of a pure aurichalcite crystalline phase with the characteristic diffraction peaks at $13.0^{\circ}, 24.2^{\circ}$, and $34.3^{\circ}$ (JCPDS 17-074). In contrast, the diffraction peaks for CZAl-HP were broadened with several new peaks at $14.6^{\circ}, 17.5^{\circ}$, and $19.4^{\circ}$. The peaks at $14.6^{\circ}$ and $17.5^{\circ}$ were assigned to rosasite (JCPDS 36-1475), while the peak at $19.4^{\circ}$ was assigned to an undefined $\mathrm{Zn}-\mathrm{Al}$ hydroxycarbonate crystalline phase [32]. The introduction of aluminum has decreased the degree of crystallization and produced a new phase in the $\mathrm{Cu}-\mathrm{Zn}-\mathrm{Al}$ hydroxycarbonate formation.

It is known that $\mathrm{Al}^{3+}$ ions do not easily coprecipitate with $\mathrm{Cu}^{2+}$ ions to form a single $\mathrm{Cu}-\mathrm{Al}$ hydroxycarbonate phase because of the distorted coordination of $\mathrm{Cu}^{2+}$ ions due to the Jahn-Teller effect [26]. Therefore, during the coprecipitation of the three cations, the $\mathrm{Al}^{3+}$ ions were partly replaced by the $\mathrm{Zn}^{2+}$ ions in the aurichalcite phase, leading to the broadening of the diffraction peaks, and the other $\mathrm{Al}^{3+}$ ions coprecipitated with $\mathrm{Zn}^{2+}$ ions to form a separate $\mathrm{Zn}-\mathrm{Al}$ hydroxycarbonate phase. These two effects drove the expulsion of $\mathrm{Zn}^{2+}$ ions from the $\mathrm{Cu}-\mathrm{Zn}$ hydroxycarbonate. According to our previous study, aurichalcite is thermodynamically favored when the $\mathrm{Cu} / \mathrm{Zn}$ molar ratio is below one, while rosasite is thermodynamically favored when the $\mathrm{Cu} / \mathrm{Zn}$ molar ratio is above one [6]. As a consequence, the decrease of the $\mathrm{Zn}^{2+}$ content in the $\mathrm{Cu}-\mathrm{Zn}$ hydroxycarbonate caused part of the aurichalcite precursor to transform to rosasite, as shown by the XRD results (Fig. 1). It indicated that the homogeneous coprecipitation of the $\mathrm{Cu}^{2+}$, $\mathrm{Zn}^{2+}$, and $\mathrm{Al}^{3+}$ ions by urea hydrolysis actually produced a mixture of different $\mathrm{Cu}-\mathrm{Zn}$-Al hydroxycarbonates.

$\mathrm{Cu}-\mathrm{ZnO}-\mathrm{Al}_{2} \mathrm{O}_{3}$ catalysts with the same $\mathrm{Cu}: \mathrm{Zn}: \mathrm{Al}$ molar ratio of 40:40:20 were also prepared by deposition-precipitation and conventional coprecipitation to modify the structure of the $\mathrm{Cu}-\mathrm{Zn}$-Al hydroxycarbonates. For the deposition-precipitation method, $\mathrm{Cu}^{2+}$ and $\mathrm{Zn}^{2+}$ ions were coprecipitated by urea hydrolysis from a well-dispersed $\mathrm{Al}(\mathrm{OH})_{3}$ gel in an aqueous solution [8]. The effect of aluminum introduction on Cu-Zn hydroxycarbonate formation is minimized in the deposition-precipitation method because the $\mathrm{Al}^{3+}$ ions are precipitated in the form of amorphous $\mathrm{Al}(\mathrm{OH})_{3}$ before the coprecipitation of the $\mathrm{Cu}^{2+}$ and $\mathrm{Zn}^{2+}$ ions. In line with this hypothesis, the $\mathrm{Cu}-\mathrm{Zn}-\mathrm{Al}$ hydroxycarbonate prepared by deposition-precipitation (denoted as CZA-DP) presented a similar XRD pattern for the binary $\mathrm{Cu}-\mathrm{Zn}$ hydroxycarbonate (CZ-HP), except that there were the additional weak diffraction peaks at $14.6^{\circ}$ and $17.5^{\circ}$ of rosasite (Fig. 1) as a result of the Ostwald ripening of the $\mathrm{Al}(\mathrm{OH})_{3}$ gel and $\mathrm{Cu}-\mathrm{Zn}$ hydroxycarbonate in the mother liquor. It was clear that CZA-DP contained a physical mixture of amorphous $\mathrm{Al}(\mathrm{OH})_{3}$ and aurichalcite. In contrast, a monophasic hydrotalcite-like $\mathrm{Cu}-\mathrm{Zn}$-Al hydroxycarbonate $\left((\mathrm{Cu}, \mathrm{Zn})_{1-x} \mathrm{Al}_{x}\right)$ $(\mathrm{OH})_{2}\left(\mathrm{CO}_{3}\right)_{x / 2}(0<x<1)$, denoted as CZA-CP, was obtained by the conventional coprecipitation method using $\mathrm{NaOH}$ and $\mathrm{Na}_{2} \mathrm{CO}_{3}$ as precipitants [26]. As shown in Fig. 1, a pure hydrotalcite-like pattern with characteristic diffraction peaks at $11.7^{\circ}, 23.4^{\circ}, 34.6^{\circ}$, and $38.9^{\circ}$ (JCPDS 37-629) was observed for CZA-CP, in which $\mathrm{Cu}^{2+}, \mathrm{Zn}^{2+}$, and $\mathrm{Al}^{3+}$ ions were distributed homogeneously at an atomic level.

In summary, structural control of the $\mathrm{Cu}-\mathrm{Zn}-\mathrm{Al}$ hydroxycar- 
bonate precursor was achieved in the different coprecipitation methods. The degree of mixing of the $\mathrm{Cu}^{2+}, \mathrm{Zn}^{2+}$, and $\mathrm{Al}^{3+}$ ions for the three samples followed the order of CZA-DP $<$ CZA-HP $<$ CZA-CP. We envisage that the difference in the distribution of the three cations in the hydroxycarbonate precursors will result in different activities for the $\mathrm{Cu}-\mathrm{ZnO}-\mathrm{Al}_{2} \mathrm{O}_{3}$ catalysts in glycerol hydrogenolysis.

\subsection{Structural characterization of the \\ hydroxycarbonate-derived $\mathrm{Cu}-\mathrm{ZnO}-\mathrm{Al}_{2} \mathrm{O}_{3}$ catalysts}

Calcination of the $\mathrm{Cu}-\mathrm{Zn}$-Al hydroxycarbonate precursors in air at $673 \mathrm{~K}$ led to ternary $\mathrm{CuO}-\mathrm{ZnO}-\mathrm{Al}_{2} \mathrm{O}_{3}$ composite oxides. Their XRD patterns were similar to that for the binary $\mathrm{CuO}-\mathrm{ZnO}$ sample formed from the $\mathrm{Cu}-\mathrm{Zn}$ hydroxycarbonate (CZ-HP). As shown in Fig. 2 , only monoclinic $\mathrm{CuO}\left(2 \theta=32.5^{\circ}, 35.7^{\circ}, 38.9^{\circ}\right.$, and $\left.49.0^{\circ}\right)$ and hexagonal $\mathrm{ZnO}\left(2 \theta=31.8^{\circ}, 34.4^{\circ}, 36.3^{\circ}\right.$, and $47.5^{\circ}$ ) appeared in the three $\mathrm{CuO}-\mathrm{ZnO}-\mathrm{Al}_{2} \mathrm{O}_{3}$ composite oxides. There was neither detectable crystalline $\mathrm{Al}_{2} \mathrm{O}_{3}$ phase nor new mixed phases of $\mathrm{CuO}, \mathrm{ZnO}$, and $\mathrm{Al}_{2} \mathrm{O}_{3}$. Compared with the binary $\mathrm{CuO}-\mathrm{ZnO}$ composite oxide, the introduction of aluminum led to the broadening of the diffraction peaks, and the broadening increased with the degree of mixing of the $\mathrm{Cu}^{2+}, \mathrm{Zn}^{2+}$, and $\mathrm{Al}^{3+}$ ions in the $\mathrm{Cu}-\mathrm{Zn}$-Al hydroxycarbonate precursors (CZA-DP< CZA-HP $<$ CZA-CP). More broadening reflects a smaller crystallite size. In line with the broadening trend, the measured crystallite sizes of the $\mathrm{CuO}$ in the oxide precursors of $\mathrm{CZ}-\mathrm{HP}$, CZA-DP, CZA-HP, CZA-CP were 10.4, 9.3, 4.5, and $3.0 \mathrm{~nm}$, respectively, while the corresponding sizes of $\mathrm{ZnO}$ were $11.8,8.4$, 6.0 , and $4.1 \mathrm{~nm}$, respectively (Table 1 ). This supported the observation that the $\mathrm{CuO}_{6}$ and $\mathrm{ZnO}_{6}$ octahedral units were dispersed by amorphous alumina during the formation of the hydroxycarbonate precursor, which in turn decreased the crystallite sizes of the $\mathrm{CuO}$ and $\mathrm{ZnO}$ domains in the composite oxides, due to the much larger surface area and higher thermal stability of the amorphous alumina. In agreement with this, the surface area of the CZ-HP oxide precursor was only $29 \mathrm{~m}^{2} / \mathrm{g}$, while those of CZA-DP, CZA-HP, and CZA-CP were 65, 101, and 97

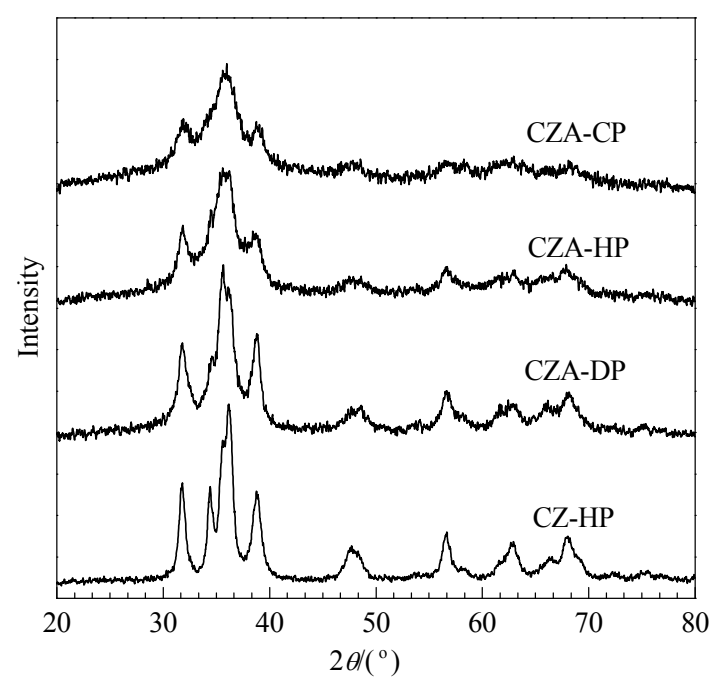

Fig. 2. XRD patterns of the $\mathrm{CuO}-\mathrm{ZnO}$ and $\mathrm{CuO}-\mathrm{ZnO}-\mathrm{Al}_{2} \mathrm{O}_{3}$ composite oxides prepared by different methods.
Table 1

BET surface area, $\mathrm{Cu}$ dispersion, and crystallite sizes for the $\mathrm{Cu}-\mathrm{ZnO}$ catalysts before and after $\mathrm{H}_{2}$ reduction at $623 \mathrm{~K}$.

\begin{tabular}{|c|c|c|c|c|c|c|c|}
\hline \multirow{2}{*}{ Catalyst } & \multicolumn{2}{|c|}{$S_{\text {BET }}\left(\mathrm{m}^{2} / \mathrm{g}\right)$} & \multirow{2}{*}{$\begin{array}{l}D_{\mathrm{Cu}^{\mathrm{a}}} \\
(\%)\end{array}$} & \multirow{2}{*}{$\begin{array}{l}d_{\mathrm{Cu} 0^{\mathrm{b}}} \\
(\mathrm{nm})\end{array}$} & \multirow{2}{*}{$\begin{array}{c}d_{\mathrm{Cu}} \mathrm{b} \\
(\mathrm{nm})\end{array}$} & \multicolumn{2}{|c|}{$d_{\mathrm{Zn} 0^{\mathrm{b}}}(\mathrm{nm})$} \\
\hline & Oxide & Reduced & & & & Oxide & Reduced \\
\hline CL-111 & 29 & 7 & 9.8 & 10.4 & 13.2 & 11.8 & 17.0 \\
\hline CZA-D & 65 & 65 & 13.8 & 9.3 & 10.9 & 8.4 & 9.1 \\
\hline CZA-HP & 101 & 84 & 15.1 & 4.5 & 8.3 & 6.0 & 6.9 \\
\hline CZA-CP & 97 & 88 & 20.7 & 3.0 & 7.4 & 4.1 & 4.9 \\
\hline
\end{tabular}

a Dispersions of $\mathrm{Cu}$ particles determined by the $\mathrm{N}_{2} \mathrm{O}$ decomposition method.

${ }^{\mathrm{b}}$ Crystallite sizes calculated from XRD.

$\mathrm{m}^{2} / \mathrm{g}$, respectively (Table 1 ).

The $\mathrm{Cu}-\mathrm{ZnO}-\mathrm{Al}_{2} \mathrm{O}_{3}$ catalysts were obtained by reduction of the $\mathrm{CuO}-\mathrm{ZnO}-\mathrm{Al}_{2} \mathrm{O}_{3}$ composite oxides in $\mathrm{H}_{2}$ at $623 \mathrm{~K}$. Figure 3 shows that the diffraction peaks of $\mathrm{CuO}$ in the oxide samples $\left(2 \theta=32.5^{\circ}, 35.7^{\circ}, 38.9^{\circ}\right.$, and $\left.49.0^{\circ}\right)$ were replaced by the peaks at $43.4^{\circ}$ and $50.6^{\circ}$ of a cubic $\mathrm{Cu}$ phase, while no change was detected for the diffraction peaks of the $\mathrm{ZnO}$ phase. This demonstrated the complete reduction of $\mathrm{CuO}$ to metallic $\mathrm{Cu}$ by $\mathrm{H}_{2}$. After reduction, the $\mathrm{Cu}$ and $\mathrm{ZnO}$ crystallite domains became larger compared to $\mathrm{CuO}$ and $\mathrm{ZnO}$ in the oxide precursors (Table 1). The crystallite sizes of $\mathrm{Cu}$ for CZ-HP, CZA-DP, CZA-HP, and CZA-CP were 13.2, 10.9, 8.3, and $7.4 \mathrm{~nm}$, and these of $\mathrm{ZnO}$ for them were 17.0, 9.1, 6.9, and $4.9 \mathrm{~nm}$, respectively. It was clear that the more homogeneous distribution of the $\mathrm{Cu}^{2+}, \mathrm{Zn}^{2+}$, and $\mathrm{Al}^{3+}$ ions in the $\mathrm{Cu}-\mathrm{Zn}-\mathrm{Al}$ hydroxycarbonate precursor led to better dispersion and thermal stability of the $\mathrm{Cu}$ and $\mathrm{ZnO}$ domains in the resulting $\mathrm{Cu}-\mathrm{ZnO}-\mathrm{Al}_{2} \mathrm{O}_{3}$ catalyst. The thermal stability of the $\mathrm{ZnO}$ domains was improved significantly by the introduction of aluminum. The size of the $\mathrm{ZnO}$ domains for the three $\mathrm{Cu}-\mathrm{ZnO}-\mathrm{Al}_{2} \mathrm{O}_{3}$ catalysts was increased slightly (but remained below $1.0 \mathrm{~nm}$ ), but the $\mathrm{ZnO}$ size in the binary CZ-HP sample was increased from 11.8 to $17.0 \mathrm{~nm}$ (by $5.2 \mathrm{~nm}$ ) after the treatment in $\mathrm{H}_{2}$ at $623 \mathrm{~K}$. In contrast, no difference was observed in the stability of $\mathrm{Cu}$ for these catalysts. This indicated that $\mathrm{Al}_{2} \mathrm{O}_{3}$ likely had much closer contact with $\mathrm{ZnO}$ than with $\mathrm{Cu}$ in the $\mathrm{Cu}-\mathrm{ZnO}-\mathrm{Al}_{2} \mathrm{O}_{3}$ catalysts, which is consistent with the co-

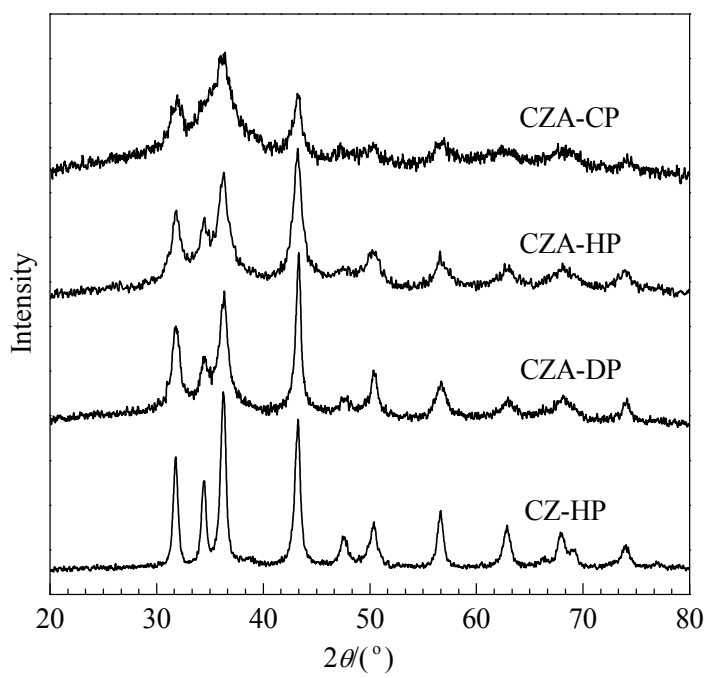

Fig. 3. XRD patterns of the $\mathrm{Cu}-\mathrm{ZnO}$ and $\mathrm{Cu}-\mathrm{ZnO}-\mathrm{Al}_{2} \mathrm{O}_{3}$ catalysts prepared by different methods. 
precipitation procedure for the preparation of the $\mathrm{Cu}-\mathrm{Zn}-\mathrm{Al}$ hydroxycarbonates. As discussed above, $\mathrm{Al}^{3+}$ ions are favored to coprecipitate with $\mathrm{Zn}^{2+}$ rather than $\mathrm{Cu}^{2+}$ because of the Jahn-Teller effect of $\mathrm{Cu}^{2+}$ ions.

The catalytic activity of the $\mathrm{Cu}-\mathrm{ZnO}-\mathrm{Al}_{2} \mathrm{O}_{3}$ catalysts was related to the dispersion of the $\mathrm{Cu}$ particles and their redox ability. The $\mathrm{Cu}$ dispersion was measured by the titration of surface $\mathrm{Cu}$ atoms with $\mathrm{N}_{2} \mathrm{O}$ at $323 \mathrm{~K}$ assuming a $\mathrm{N}_{2} \mathrm{O} / \mathrm{Cu}_{\text {surface }}$ stoichiometry of 0.5 [33]. Table 1 shows that the $\mathrm{Cu}$ dispersion for CZ-HP, CZA-DP, CZA-HP, and CZA-CP was 9.8\%, 13.8\%, 15.1\%, and $20.7 \%$, respectively. The good correlation between the $\mathrm{Cu}$ dispersion and $\mathrm{Cu}$ crystallite size in the $\mathrm{Cu}-\mathrm{ZnO}-\mathrm{Al}_{2} \mathrm{O}_{3}$ catalysts implied that most of the $\mathrm{Cu}$ particles were accessible on the catalyst surface. In addition, the redox ability of the surface $\mathrm{Cu}$ atoms was examined by $\mathrm{H}_{2}$ TPR of the surface $\mathrm{Cu}_{2} \mathrm{O}$ species, which were formed by $\mathrm{N}_{2} \mathrm{O}$ oxidation of the pre-reduced $\mathrm{Cu}-\mathrm{ZnO}-\mathrm{Al}_{2} \mathrm{O}_{3}$ catalysts. According to our previous study, a lower reduction temperature of the surface $\mathrm{Cu}_{2} \mathrm{O}$ species reflects a higher redox activity of the $\mathrm{Cu}$ particles [6]. As depicted in Fig. 4, a single TPR peak at $436 \mathrm{~K}$ was detected on CZ-HP, which was consistent with the uniformly sized $\mathrm{Cu}$ particles derived from the monophasic aurichalcite of the binary $\mathrm{Cu}-\mathrm{Zn}$ hydroxycarbonate precursor. In contrast, two TPR peaks of $\mathrm{Cu}_{2} \mathrm{O}$ species were observed on CZA-HP (431 and $444 \mathrm{~K}$ ) and CZA-DP (443 and $454 \mathrm{~K}$ ), indicating the presence of two kinds of $\mathrm{Cu}$ particles on the catalyst surface. These reflect different $\mathrm{Cu}$ dispersions or different metal-support interactions. As discussed above, the introduction of aluminum into the $\mathrm{Cu}-\mathrm{Zn}$ hydroxycarbonate precursors by homogeneous coprecipitation and deposition-precipitation induced a phase transition from aurichalcite to rosasite. The $\mathrm{Cu}$ particles derived from the rosasite phase were less active than those from the aurichalcite phase. Therefore, the low temperature peak was correlated with aurichalcite, and the high temperature peak with rosasite. This assignment was confirmed by that the area ratio of the high temperature peak to the low temperature peak on CZA-HP was larger than that on CZA-DP (1.4 vs 0.67 ), in agreement with that CZA-HP possessed a larger fraction of the rosasite phase in its $\mathrm{Cu}-\mathrm{Zn}-\mathrm{Al}$ hydroxycarbonate precursor. Different from

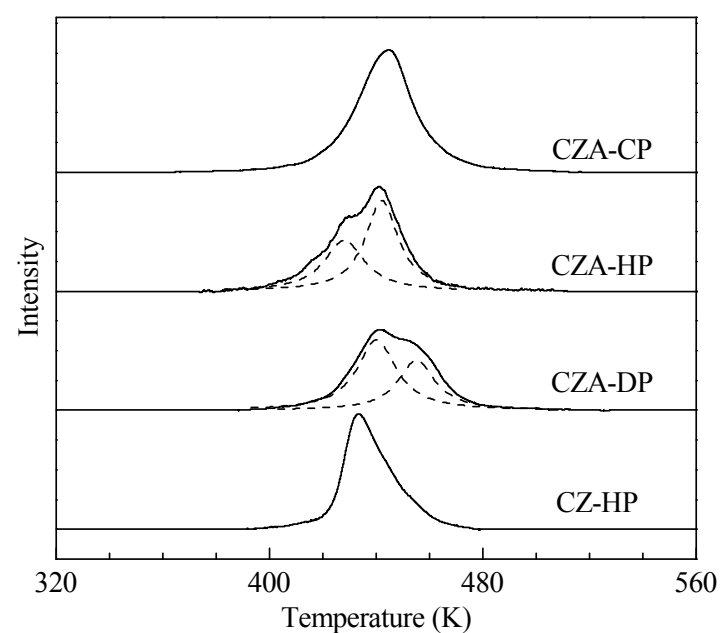

Fig. 4. $\mathrm{H}_{2}$-TPR profiles for the $\mathrm{Cu}-\mathrm{ZnO}$ and $\mathrm{Cu}-\mathrm{ZnO}-\mathrm{Al}_{2} \mathrm{O}_{3}$ catalysts prepared by different methods after exposure to $\mathrm{N}_{2} \mathrm{O}$ at $323 \mathrm{~K}$.
CZA-HP and CZA-DP, CZA-CP presented a single TPR peak at $447 \mathrm{~K}$, in line with the pure hydrotalcite-like $\mathrm{Cu}-\mathrm{Zn}$-Al hydroxycarbonate precursor formed by the conventional coprecipitation method.

The redox activity of the $\mathrm{Cu}$ particles in the $\mathrm{Cu}-\mathrm{ZnO}-\mathrm{Al}_{2} \mathrm{O}_{3}$ catalysts was determined by two factors, namely, the size of the $\mathrm{Cu}$ particles and the interaction between $\mathrm{Cu}$ and $\mathrm{ZnO}$. For instance, the redox activity of the $\mathrm{Cu}$ particles derived from aurichalcite followed the order of CZA-DP $<$ CZ-HP $<$ CZA-HP. On one hand, the lower activity of CZA-DP compared with CZ-HP indicated that the introduction of aluminum hindered the interaction between $\mathrm{Cu}$ and $\mathrm{ZnO}$ although the $\mathrm{Cu}$ size was smaller in CZA-DP than in CZ-HP (10.9 vs $13.2 \mathrm{~nm}$ ). On the other hand, the size effect resulted in the higher activity of CZA-HP because the $\mathrm{Cu}$ size in CZA-HP was further decreased to $8.3 \mathrm{~nm}$ by a better dispersion by alumina. Similarly, the homogeneous mixing of $\mathrm{Al}_{2} \mathrm{O}_{3}$ gave the less active $\mathrm{Cu}$ particles on CZA-CP than those derived from aurichalcite on CZA-HP (447 vs $431 \mathrm{~K}$ ), although CZA-CP possessed the smallest $\mathrm{Cu}$ particles $(7.4 \mathrm{~nm})$ of the four catalysts. The hydrotalcite-like $\mathrm{Cu}-\mathrm{Zn}-\mathrm{Al}$ hydroxycarbonate precursor did not give a strong $\mathrm{Cu}-\mathrm{ZnO}$ interaction in the final $\mathrm{Cu}-\mathrm{ZnO}-\mathrm{Al}_{2} \mathrm{O}_{3}$ catalyst [26].

These structural characterization results for the hydroxycarbonate-derived $\mathrm{Cu}-\mathrm{ZnO}-\mathrm{Al}_{2} \mathrm{O}_{3}$ catalysts showed that the structure and properties of the $\mathrm{Cu}$ particles of the $\mathrm{Cu}-\mathrm{ZnO}-\mathrm{Al}_{2} \mathrm{O}_{3}$ catalysts were dependent on their $\mathrm{Cu}-\mathrm{Zn}-\mathrm{Al}$ hydroxycarbonate precursor. This relationship provides a way to tune the activity of the $\mathrm{Cu}-\mathrm{ZnO}-\mathrm{Al}_{2} \mathrm{O}_{3}$ catalysts by changing the degree of mixing of aluminum in the $\mathrm{Cu}-\mathrm{Zn}-\mathrm{Al}$ hydroxycarbonate precursor.

\subsection{Activity, selectivity, and stability of $\mathrm{Cu}-\mathrm{ZnO}-\mathrm{Al}_{2} \mathrm{O}_{3}$ catalysts in glycerol hydrogenolysis}

Table 2 shows the activities and selectivities of the $\mathrm{Cu}-\mathrm{ZnO}-\mathrm{Al}_{2} \mathrm{O}_{3}$ catalysts in glycerol hydrogenolysis at $473 \mathrm{~K}$ and 6.0 $\mathrm{MPa} \mathrm{H}_{2}$. The glycerol conversions were kept at about $30 \%$ to be in the kinetic controlled regime. The activity of the $\mathrm{Cu}-\mathrm{ZnO}-\mathrm{Al}_{2} \mathrm{O}_{3}$ catalysts was evaluated by the glycerol conversion rate normalized to the surface $\mathrm{Cu}$ atoms of the fresh catalyst, i.e., the turnover frequencies (TOFs). As shown in Table 2, glycerol was converted to propylene glycol with a high selectivity of above $90 \%$ on all these $\mathrm{Cu}-\mathrm{ZnO}-\mathrm{Al}_{2} \mathrm{O}_{3}$ catalysts regardless of their preparation methods. Ethylene glycerol was the main byproduct with a selectivity of $6 \%-10 \%$, while trace amounts of methanol, 1-propanol, methane, and $\mathrm{CO}_{2}$ were also detected in the products. In contrast to the similar selectivities, these $\mathrm{Cu}-\mathrm{ZnO}-\mathrm{Al}_{2} \mathrm{O}_{3}$ catalysts showed different TOFs in glycerol hydrogenolysis with the order of CZA-HP (5.7 mmol glycer-

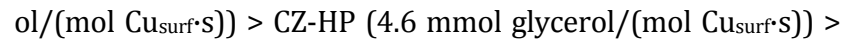
CZA-CP (4.4 mmol glycerol/(mol Cusurf $\bullet$ ) ) > CZA-DP (2.8 mmol glycerol/(mol $\left.\left.\mathrm{Cu}_{\text {surf }} \cdot \mathrm{s}\right)\right)$. It was clear that the homogeneous coprecipitation method provided more active $\mathrm{Cu}-\mathrm{ZnO}$-based catalysts than the conventional coprecipitation and deposition-precipitation methods.

Our previous study suggested that glycerol first dehydrogenated to glyceraldehyde on the $\mathrm{Cu}$ surface $[6,20]$, which then 
Table 2

Turnover frequency and selectivity in glycerol hydrogenolysis of the $\mathrm{Cu}-\mathrm{ZnO}$ and $\mathrm{Cu}-\mathrm{ZnO}-\mathrm{Al}_{2} \mathrm{O}_{3}$ catalysts.

\begin{tabular}{|c|c|c|c|c|c|c|}
\hline \multirow{2}{*}{ Catalyst } & \multirow{2}{*}{$\begin{array}{c}\text { Conversion } \\
(\%)\end{array}$} & \multirow{2}{*}{$\begin{array}{c}\text { TOF } \\
(\text { mmol glycerol } /(\mathrm{mol} \mathrm{Cu} \text { surf } s))\end{array}$} & \multicolumn{4}{|c|}{ Selectivity (\%) } \\
\hline & & & Propylene glycol & Ethylene glycol & Methanol & Others* \\
\hline CZ-HP & 28.5 & 4.6 & 93.9 & 6.0 & 0.1 & trace \\
\hline CZA-HP & 31.0 & 5.7 & 91.6 & 8.2 & 0.2 & 0.1 \\
\hline CZA-DP & 30.2 & 2.8 & 91.2 & 8.8 & trace & trace \\
\hline CZA-CP & 31.8 & 4.4 & 90.1 & 9.9 & trace & trace \\
\hline
\end{tabular}

Reaction conditions: $10 \mathrm{wt} \%$ aqueous glycerol solution $50 \mathrm{~g}, 473 \mathrm{~K}, 6.0 \mathrm{MPa} \mathrm{H}_{2}, 6 \mathrm{~h}$, ca. $30 \%$ glycerol conversion obtained by varying catalyst amount.

*Including 1-propanol, methane, and $\mathrm{CO}_{2}$.

dehydrates to pyruvaldehyde to cleave a terminal $\mathrm{C}-\mathrm{O}$ bond, followed by sequential hydrogenation to acetol and ultimately propylene glycol (Scheme 1). Alternately, the glyceraldehyde intermediate can dehydrogenate on the $\mathrm{Cu}$ surface to 2-hydroxymalonaldehyde, which then cleaves a terminal $\mathrm{C}-\mathrm{C}$ bond via the retro-Claisen mechanism to formic acid and 2-hydroxyacetaldehyde. Formic acid further decomposes to $\mathrm{CO}_{2}$ or hydrogenates to methanol, while 2-hydroxyacetaldehyde hydrogenates to ethylene glycerol. Glycerol dehydrogenation to glyceraldehyde was assumed to be the rate limiting step. As a consequence, the activity of the $\mathrm{Cu}$-based catalysts correlates with the redox ability of $\mathrm{Cu}$ particles, which is consistent with the studies with binary $\mathrm{Cu}-\mathrm{ZnO}$ catalysts [6]. It is interesting that the TOFs of the $\mathrm{Cu}-\mathrm{ZnO}-\mathrm{Al}_{2} \mathrm{O}_{3}$ catalysts in glycerol hydrogenolysis did not strictly follow the redox ability of the $\mathrm{Cu}$ particles revealed from the $\mathrm{H}_{2}$-TPR of surface $\mathrm{Cu}_{2} \mathrm{O}$ species. For instance, CZA-HP and CZ-HP showed similar reduction temperatures around $438 \mathrm{~K}$, but CZA-HP gave higher hydrogenolysis activity than CZ-HP (5.7 vs $4.6 \mathrm{mmol} /$ glycerol/(mol $\left.\mathrm{Cu}_{\text {surf }} \cdot \mathrm{s}\right)$ ). CZA-CP and CZA-DP also showed similar reduction temperatures around $447 \mathrm{~K}$, but the TOF of CZA-CP was higher than that of CZA-DP (4.4 vs $2.8 \mathrm{mmol}$ glycerol/(mol Cusurf $s$ )), which was close to CZ-HP. This deviation in the correlation came from the increase of $\mathrm{Cu}$ particle size in glycerol hydrogenolysis due to that small $\mathrm{Cu}$ particles are more active than large $\mathrm{Cu}$ particles [6,23]. The Cu particle size on CZ-HP was increased to 17.0 $\mathrm{nm}$ after the reaction, while the presence of alumina stabilized the $\mathrm{Cu}$ particle size at $13.4 \mathrm{~nm}$ on CZA-HP in the reaction. Similarly, the $\mathrm{Cu}$ particle size of CZA-CP and CZA-DP were increased to 12.1 and $17.1 \mathrm{~nm}$, respectively. It was obvious that the
$\mathrm{Cu}-\mathrm{ZnO}-\mathrm{Al}_{2} \mathrm{O}_{3}$ catalysts derived from the $\mathrm{Cu}-\mathrm{Zn}-\mathrm{Al}$ hydroxycarbonate precursors with atomic mixing of $\mathrm{Cu}^{2+}, \mathrm{Zn}^{2+}$, and $\mathrm{Al}^{3+}$ ions, such as CZA-HP and CZA-CP, exhibited higher stability of the $\mathrm{Cu}$ particles, and thus higher activity in glycerol hydrogenolysis. The inferior activity of CZA-CP compared with CZA-HP, considering their similar $\mathrm{Cu}$ particle sizes and stability, appeared to be due to its superior dispersion of $\mathrm{Al}_{2} \mathrm{O}_{3}$, which inhibited the interaction between $\mathrm{Cu}$ and $\mathrm{ZnO}$. These results suggested that the roles of alumina in hindering $\mathrm{Cu}-\mathrm{ZnO}$ interaction and in the improvement of $\mathrm{Cu}$ dispersion and stability need to be taken into account to optimize $\mathrm{Cu}-\mathrm{ZnO}-\mathrm{Al}_{2} \mathrm{O}_{3}$ catalysts.

The promoting effect of alumina on the catalyst stability was examined by comparing CZ-HP and CZA-HP in recycling experiments at $473 \mathrm{~K}$ and $6.0 \mathrm{MPa} \mathrm{H}_{2}$. During the recycling, the used catalysts were collected from the liquid product by filtration, washed sufficiently with deionized water and then dried under vacuum for the next run. As show in Fig. 5, the activity of the two catalysts gradually decreased and reached constant values after four runs. An activity loss of $45 \%$ was observed for CZ-HP in six cycles with a total reaction time of $36 \mathrm{~h}$, while the corresponding loss for CZA-HP was only 10\%. ICP measurements of the used catalysts showed negligible leaching of $\mathrm{Cu}$ during the recycling. Thus, the agglomeration of the $\mathrm{Cu}$ particles would be the main reason for their deactivation, which was confirmed by the XRD results revealing that the $\mathrm{Cu}$ particle size in the CZ-HP sample after six cycles was increased to $45.2 \mathrm{~nm}$ and was much larger than the size for CZA-HP (19.0 nm). Clearly, the addition of alumina into the $\mathrm{Cu}-\mathrm{ZnO}$ catalysts not only improved the activity of the catalysts, but also prevented

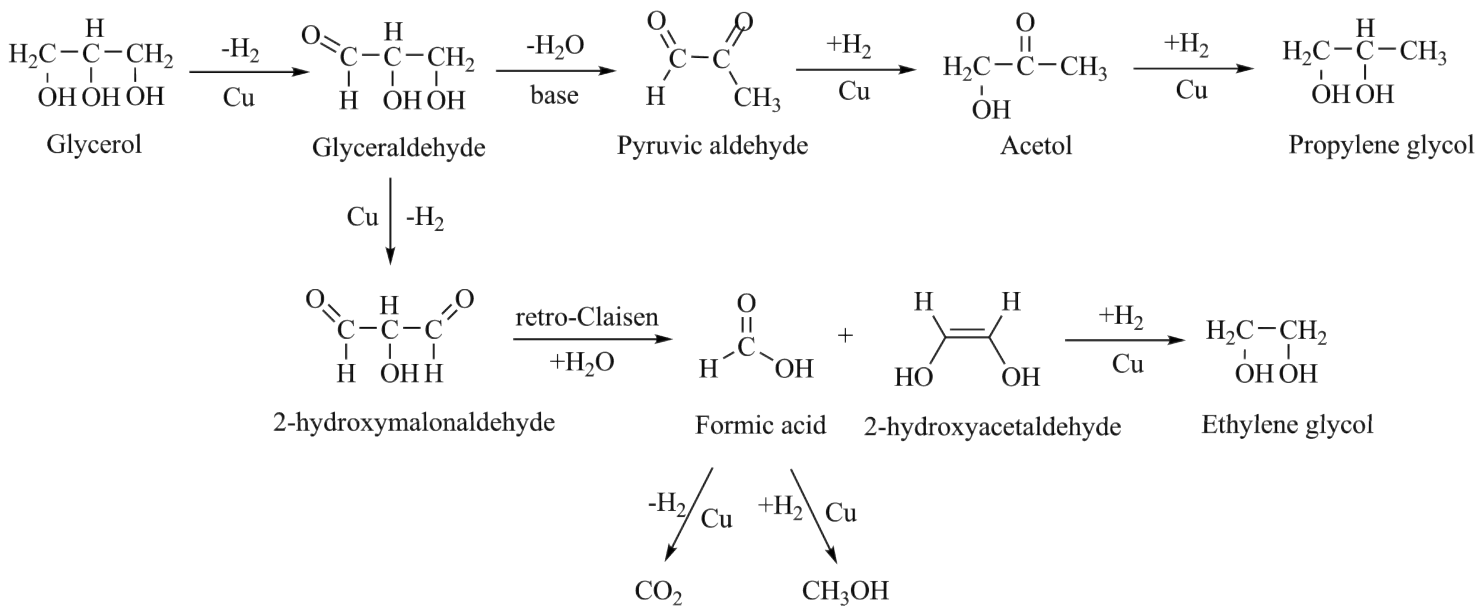

Scheme 1. Pathways for cleavage of C-O and C-C bonds in glycerol hydrogenolysis on Cu-based catalysts [6]. 


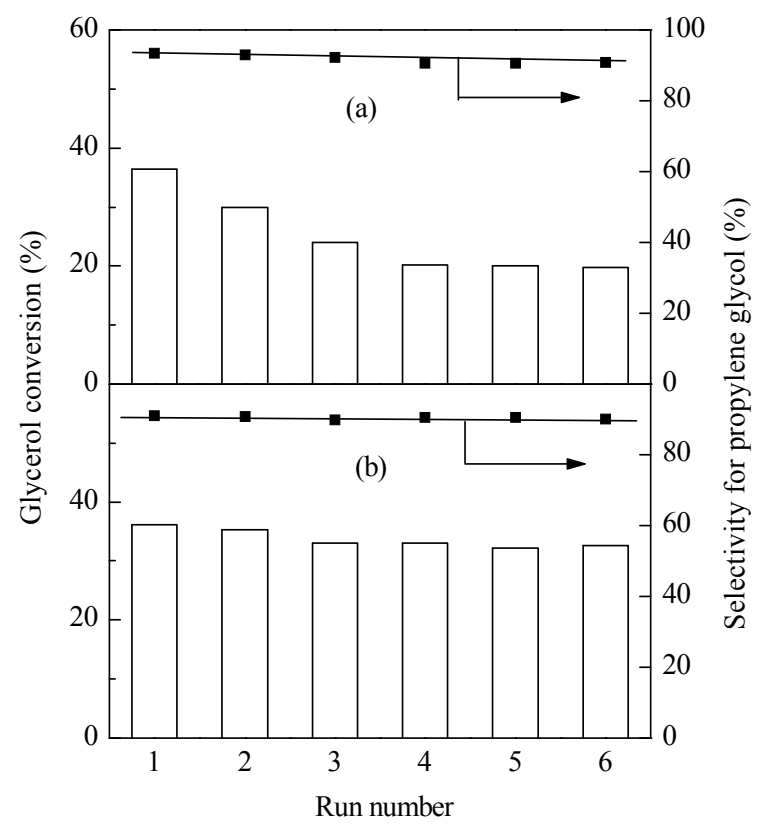

Fig. 5. Glycerol conversions and selectivities for propylene glycol in six consecutive cycles of glycerol hydrogenolysis on a $\mathrm{Cu}-\mathrm{ZnO}$ catalyst (CZ-HP) (a) and a $\mathrm{Cu}-\mathrm{ZnO}-\mathrm{Al}_{2} \mathrm{O}_{3}$ catalyst (CZA-HP) (b) prepared via homogeneous coprecipitation. Reaction conditions: $10 \mathrm{wt} \%$ aqueous glycerol solution $50 \mathrm{~g}, 473 \mathrm{~K}, 6.0 \mathrm{MPa} \mathrm{H}_{2}, 6 \mathrm{~h}$.

their deactivation.

It is worth mentioning that the selectivities of the catalysts remained essentially unaltered in the recycling reactions (Fig. 5), indicating that unlike the activity, the selectivity was not sensitive to the $\mathrm{Cu}$ particle size. The underlying reason needs to be clarified. However, we noticed that the presence of $\mathrm{Al}_{2} \mathrm{O}_{3}$ in the $\mathrm{Cu}-\mathrm{ZnO}$ based catalysts slightly decreased the propylene glycol selectivity from $93.9 \%$ (CZ-HP) to $91.6 \%$ (CZA-HP), with a concurrent increase in the ethylene glycol selectivity from $6.0 \%$ to $8.2 \%$. A similar decrease of the selectivity to propylene glycol was also found on CZA-CP (90.1\%) and CZA-DP (91.2\%). We proposed that the selectivity of propylene glycol to ethylene glycol was mainly determined by the dehydration rate of glyceraldehyde to pyruvaldehyde (Scheme 1), which drives the step of $\mathrm{C}-\mathrm{O}$ bond cleavage. Glyceraldehyde dehydration was suggested to be catalyzed by basic sites on an oxide support when the reaction was carried out in a neutral aqueous solution [13]. Specifically, the acidic $\alpha-\mathrm{H}$ of glyceraldehyde is abstracted by the lattice oxygen on $\mathrm{ZnO}$, which is followed by a nucleophilic attack of the $\beta-\mathrm{OH}$ group to form $\mathrm{H}_{2} \mathrm{O}$ and pyruvaldehyde (Scheme 2). It is known that $\mathrm{Al}_{2} \mathrm{O}_{3}$ is more acidic than $\mathrm{ZnO}$ [34]. The mixing of $\mathrm{Al}_{2} \mathrm{O}_{3}$ with $\mathrm{ZnO}$ thus decreased the basicity of the support surface, and consequently decreased the glyceraldehyde dehydration rate and the selectivity to propyl- ene glycol. This is consistent with that fact that CZA-CP with the highest $\mathrm{Al}_{2} \mathrm{O}_{3}$ dispersion among the three $\mathrm{Cu}-\mathrm{ZnO}-\mathrm{Al}_{2} \mathrm{O}_{3}$ catalysts exhibited the lowest selectivity to propylene glycol (Table 2).

\section{Conclusions}

The activity and stability of $\mathrm{Cu}-\mathrm{ZnO}$ catalysts in glycerol hydrogenolysis were improved by the addition of $\mathrm{Al}_{2} \mathrm{O}_{3}$ during the preparation of the $\mathrm{Cu}-\mathrm{Zn}-\mathrm{Al}$ hydroxycarbonate precursor, such as Al-substituted aurichalcite, with a homogeneous mixing of $\mathrm{Cu}^{2+}, \mathrm{Zn}^{2+}$, and $\mathrm{Al}^{3+}$ ions at the atomic level. $\mathrm{Cu}$ and $\mathrm{ZnO}$ domains were dispersed by amorphous $\mathrm{Al}_{2} \mathrm{O}_{3}$ that gave enhanced thermal stability through an intimate contact between $\mathrm{ZnO}$ and $\mathrm{Al}_{2} \mathrm{O}_{3}$ in the $\mathrm{Cu}-\mathrm{ZnO}-\mathrm{Al}_{2} \mathrm{O}_{3}$ catalysts, which resulted in smaller $\mathrm{Cu}$ particles, and consequently higher redox ability and superior hydrogenolysis activity. However, too intimate a $\mathrm{ZnO}-\mathrm{Al}_{2} \mathrm{O}_{3}$ contact hinders the strong interaction between $\mathrm{Cu}$ and $\mathrm{ZnO}$, which is unfavorable for the activity of the $\mathrm{Cu}$ particles. Furthermore, the addition of $\mathrm{Al}_{2} \mathrm{O}_{3}$ led to a decrease in the basicity of the $\mathrm{Cu}-\mathrm{ZnO}$ catalysts, and consequently a slight decline in the selectivity to propylene glycol because the cleavage of the terminal $\mathrm{C}-\mathrm{O}$ bond of glycerol occurs via base-catalyzed glyceraldehyde dehydration. These results showed the improvement in the activity, selectivity, and stability of $\mathrm{Cu}-\mathrm{ZnO}-\mathrm{Al}_{2} \mathrm{O}_{3}$ catalysts in glycerol hydrogenolysis by adding $\mathrm{Al}_{2} \mathrm{O}_{3}$ and using its interaction with $\mathrm{Cu}$ and $\mathrm{ZnO}$.

\section{References}

[1] Ruppert A M, Weinberg K, Palkovits R. Angew Chem Int Ed, 2012, 51: 2564

[2] Besson M, Gallezot P, Pinel C. Chem Rev, 2014, 114: 1827

[3] Nakagawa Y, Tomishige K. Catal Sci Technol, 2011, 1: 179

[4] ten Dam J, Hanefeld U. ChemSusChem, 2011, 4: 1017

[5] Zhou C H, Zhao H, Tong D S, Wu L M, Yu W H. Catal Rev Sci Eng, 2013, 55: 369

[6] Wang S, Zhang Y, Liu H. Chem Asian J, 2010, 5: 1100

[7] Huang Z, Cui F, Kang H, Chen J, Zhang X, Xia C. Chem Mater, 2008, 20: 5090

[8] Huang Z, Cui F, Xue J, Zuo J, Chen J, Xia C. Catal Today, 2012, 183: 42

[9] Zhao L L, Chen J X. Chin J Catal (赵兰兰, 陈吉祥. 催化学报), 2012, 33: 1410

[10] Panyada S, Jongpatiwut S, Sreethawong T, Rirksomboon T, Osuwan S. Catal Today, 2011, 174: 59

[11] Zhou Z M, Li X, Zeng T Y, Hong W B, Cheng Z M, Yuan W K. Chin J Chem Eng, 2010, 18: 384

[12] Yuan Z, Wang L, Wang J, Xia S, Chen P, Hou Z, Zheng X. Appl Catal $B, 2011,101: 431$

[13] Wang S, Yin K, Zhang Y, Liu H. ACS Catal, 2013, 3: 2112

[14] Feng J, Xiong W, Jia Y, Wang J B, Liu D R, Chen H, Li X J. Chin J Catal

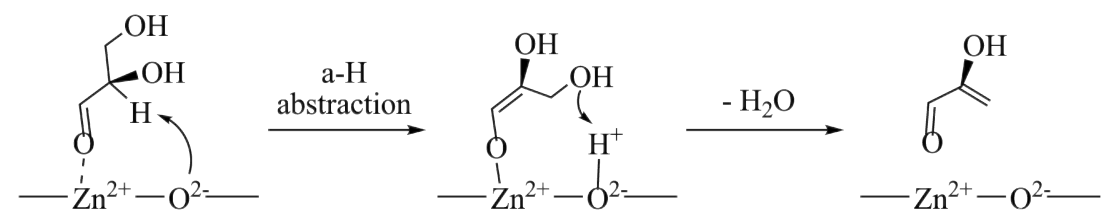

Scheme 2. Pathway of glyceraldehyde dehydration on the basic sites of ZnO. 


\title{
Graphical Abstract
}

Chin. J. Catal., 2014, 35: 631-643 doi: 10.1016/S1872-2067(14)60094-2

\section{Selective hydrogenolysis of glycerol to propylene glycol on hydroxycarbonate-derived $\mathrm{Cu}-\mathrm{ZnO}-\mathrm{Al}_{2} \mathrm{O}_{3}$ catalysts}

Shuai Wang, Haichao Liu*

Peking University

The activity and stability of $\mathrm{Cu}-\mathrm{ZnO}$ catalysts for glycerol hydrogenolysis to propylene glycol were enhanced by the introduction of aluminum in the Cu-Zn hydroxycarbonate precursor in the preparation of the catalyst.

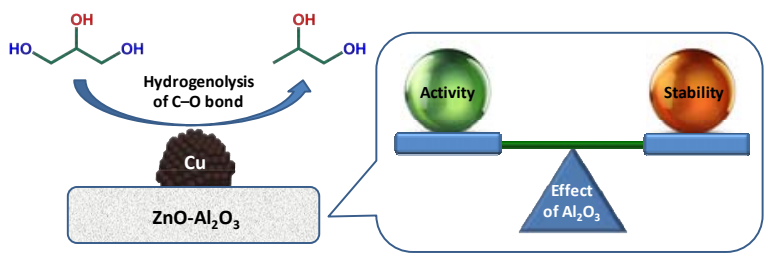

(冯建，熊伟，贾云，王金波，刘德蓉，陈华，李贤均. 催化学报), 2011, 32: 1545

[15] Ma L, Li Y M, He D H. Chin J Catal (马兰, 李宇明, 贺德华. 催化学 报), 2011, 32: 872

[16] Guan J, Chen X F, Peng G M, Wang X C, Cao Q, Lan Z G, Mu X D. Chin $J$ Catal (关静, 陈秀芳, 彭功名, 王喜成, 曹泉, 兰峥岗, 牟新东. 催 化学报), 2013, 34: 1656

[17] Tan H, Hedhill M N, Wang Y, Zhang J, Li K, Sioud S, Al-Talla Z A, Amad M H, Zhan T, Talla O E, Han Y. Catal Sci Technol, 2013, 3: 3360

[18] Durán-Martín D, Ojeda M, Granados M L, Fierro J L G, Mariscal R. Catal Today, 2013, 210: 98

[19] Vasiliadou E S, Eggenhuisen T M, Munnik P, de Jongh P E, de Jong K P, Lemonidou A A. Appl Catal B, 2014, 145: 108

[20] Wang S, Li Y, Liu H C. Acta Chim Sin (王帅, 李洋, 刘海超. 化学学 报), 2012, 70: 1897

[21] Montassier C, Dumas J M, Granger P, Barbier J. Appl Catal A, 1995, 121: 231

[22] Bienholz A, Blume R, Knop-Gericke A, Girgsdies F, Behrens M,
Claus P.J Phys Chem C, 2011, 115: 999

[23] Wang S, Liu H. Catal Lett, 2007, 117: 62

[24] Behrens M, Zander S, Kurr P, Jacobsen N, Senker J, Koch G, Ressler T, Fischer R W, Schlögl R. J Am Chem Soc, 2013, 135: 6061

[25] Shishido T, Yamamoto M, Li D, Tian Y, Morioka H, Honda M, Sano T, Takehira K. Appl Catal A, 2006, 303: 62

[26] Behrens M, Kasatkin I, Kühl S, Weinberg G. Chem Mater, 2010, 22: 386

[27] Millar G J, Holm I H, Uwins P J R, Drennan J. J Chem Soc, Faraday Trans, 1998, 94: 593

[28] Baltes C, Vukojević S, Schüth F. J Catal, 2008, 258: 334

[29] Behrens M, Schlogl R. Z Anorg Allg Chem, 2013, 639: 2683

[30] Behrens M, Girgsdies F, Trunschke A, Schlögl R. Eur J Inorg Chem, 2009: 1347

[31] Behrens M. J Catal, 2009, 267: 24

[32] Miao S, d'Alnoncourt R N, Reinecke T, Kasatkin I, Behrens M, Schlögl R, Muhle M. Eur J Inorg Chem, 2009: 910

[33] Bond G C, Namijo S N. J Catal, 1989, 118: 507

[34] Wang J, Zeng C. J Nat Gas Chem, 2005, 14: 156

\section{$\mathrm{Cu}-\mathrm{ZnO}-\mathrm{Al}_{2} \mathrm{O}_{3}$ 复合催化剂上甘油选择氢解合成丙二醇}

\author{
王 帅, 刘海超* \\ 北京大学化学与分子工程学院, 北京分子科学国家实验室, 分子动态与稳态结构国家重点实验室, 北京100871
}

摘要: 分别采用均匀共沉淀法、沉积-沉淀法和传统的共沉淀法制备了 3 种具有相似组成的 Cu- $\mathrm{ZnO}-\mathrm{Al}_{2} \mathrm{O}_{3}$ 催化剂(CZA-HP, CAZ-DP和CZA-CP); 同时还采用均匀共沉淀法制备了 Cu-ZnO催化剂(CZ-HP)以用于比较. X射线衍射表征结果表明, 以上方法制 备的 Cu-Zn-Al碱式碳酸盐前体中 $\mathrm{Cu}^{2+}, \mathrm{Zn}^{2+}$ 和 $\mathrm{Al}^{3+}$ 的混合均匀程度的顺序为CZA-DP $<\mathrm{CZA}-\mathrm{HP}<\mathrm{CZA}-\mathrm{CP}$. $\mathrm{Al}^{3+}$ 分散程度的提高和 $\mathrm{Al}_{2} \mathrm{O}_{3}$ 与 $\mathrm{ZnO}$ 的紧密接触使得 $\mathrm{Cu}-\mathrm{ZnO}-\mathrm{Al}_{2} \mathrm{O}_{3}$ 催化剂中金属 $\mathrm{Cu}$ 和 $\mathrm{ZnO}$ 具有更小的粒径. 但 $\mathrm{ZnO}-\mathrm{Al}_{2} \mathrm{O}_{3}$ 间紧密接触也阻隔了 $\mathrm{Cu}-\mathrm{ZnO}-\mathrm{Al}_{2} \mathrm{O}_{3}$ 催化剂中金属 $\mathrm{Cu}$ 与 $\mathrm{ZnO}$ 之间的相互作用. 因此 $\mathrm{Al}_{2} \mathrm{O}_{3}$ 的添加使得 $\mathrm{CZA}-\mathrm{HP}$ 样品上的 $\mathrm{Cu}$ 粒子表现出最强的氧化还原能 力. 在 $473 \mathrm{~K}$ 和 $6.0 \mathrm{MPa} \mathrm{H}$ 的反应条件下, 以上三种 $\mathrm{Cu}-\mathrm{ZnO}-\mathrm{Al}_{2} \mathrm{O}_{3}$ 催化剂均高选择性地催化甘油氢解为丙二醇 $(30 \%$ 甘油转化率下 的选择性 $>90 \%$ ). $\mathrm{Cu}-\mathrm{ZnO}-\mathrm{Al}_{2} \mathrm{O}_{3}$ 催化剂表面单位 $\mathrm{Cu}$ 原子的本征活性顺序为CZA-DP $<\mathrm{CZA}-\mathrm{CP}<\mathrm{CZ}-\mathrm{HP}<\mathrm{CZA}-\mathrm{HP}$, 与它们的氧 化还原能力相一致. 此外, $\mathrm{Al}_{2} \mathrm{O}_{3}$ 的添加还显著地抑制了 $\mathrm{Cu}$ 粒子在反应过程中的聚集, 提高了催化剂的稳定性. 经6次循环使用后, CZ-HP中Cu粒子的粒径从13.2增至 $45.2 \mathrm{~nm}$, 活性相应下降了 45\%; 而CZA-HP中Cu粒子的粒径从 8.3 增至 $19.0 \mathrm{~nm}$, 活性仅下降了 $10 \%$.

关键词: 甘油; 选择性氢解; 丙二醇; 铜; 氧化锌; 氧化铝; 碱式碳酸盐前体; 构效关系; 催化剂稳定性

收稿日期: 2014-03-20. 接受日期: 2014-03-27. 出版日期: 2014-05-20.

*通讯联系人. 电话/传真: (010)62754031; 电子信箱: hcliu@pku.edu.cn

基金来源：国家重点基础研究发展计划(973计划，2011CB201400，2011CB808700); 国家自然科学基金(21173008, 21373019, 51121091).

本文的英文电子版由Elsevier出版社在ScienceDirect上出版(http://www.sciencedirect.com/science/journal/18722067). 


\section{1. 前言}

甘油选择性氢解制取丙二醇是利用生物柴油生产 过程中大量联产甘油的有效途径之一, 并在近十年中得 到了广泛的研究 ${ }^{[1-5]}$. $\mathrm{Cu}$ 基催化剂, 例如, $\mathrm{Cu}-\mathrm{ZnO}^{[6]}$, $\mathrm{Cu}-\mathrm{SiO}_{2}{ }^{[7,8]}, \mathrm{Cu} / \mathrm{Al}_{2} \mathrm{O}_{3}{ }^{[9]}, \mathrm{Cu}-\mathrm{ZnO}-\mathrm{Al}_{2} \mathrm{O}_{3}{ }^{[10,11]}$ 和 $\mathrm{Cu} / \mathrm{MgO}-$ $\mathrm{Al}_{2} \mathrm{O}_{3}{ }^{[12]}$ 等, 均在高的甘油转化率下 $(>75 \%)$ 表现出高于 $90 \%$ 的丙二醇选择性. 与之相反, VIII族金属催化剂, 如 $\mathrm{Ru}, \mathrm{Rh}, \mathrm{Pt}$ 和Ni等, 倾向于断裂甘油的C-C键而生成乙二 醇, 甚至甲烷等深度氢解产物 ${ }^{[13-16]}$. 相对于 $\mathrm{Cu}$ 基催化剂 突出的丙二醇选择性, 其本征催化活性以及水热稳定性 却低于VIII族金属催化剂 ${ }^{[1,2]}$. 因此, 如何提高 $\mathrm{Cu}$ 粒子的 活性和在甘油氢解反应水热条件下的稳定性是进一步 设计合成高效铜基催化剂的关键. 相关研究表明 ${ }^{[6,17]}$, 小尺寸的 $\mathrm{Cu}$ 粒子以及金属 $\mathrm{Cu}$ 与载体之间的强相互作用 均可以提高 $\mathrm{Cu}$ 粒子的氧化还原活性, 从而提高其催化甘 油氢解活性. 这缘于甘油在金属表面脱氢为甘油醛是甘 油氢解反应的决速步 ${ }^{[6]}$. 此外, 使用高水热稳定性载体 可以抑制 $\mathrm{Cu}$ 粒子在水相氢解反应中的聚集 ${ }^{[21]}$. Bienholz 等 ${ }^{[22]}$ 发现, 在 $\mathrm{Cu}-\mathrm{ZnO}$ 催化剂中引入 $\mathrm{Ga}_{2} \mathrm{O}_{3}$ 显著地提高了 $\mathrm{Cu}$ 粒子的稳定性, 循环使用四次后 $\left(473 \mathrm{~K}, 5.0 \mathrm{MPa} \mathrm{H}_{2}\right.$, 累积反应时间 $20 \mathrm{~h}$ ), 催化剂活性没有明显下降 $(<10 \%)$.

我们此前的研究表明, 以尿素为沉淀剂的均匀共沉 淀方法可以制备 $\mathrm{Cu}^{2+}$ 和 $\mathrm{Zn}^{2+}$ 离子均匀混合的 $\mathrm{Cu}-\mathrm{Zn}$ 碱式 碳酸盐前体, 从而得到具有小尺寸 $\mathrm{Cu}$ 粒子和强金属-载 体相互作用的 $\mathrm{Cu}-\mathrm{ZnO}$ 催化剂 ${ }^{[6,23]}$. 该催化剂在甘油选择 氢解反应中表现出良好的活性和丙二醇选择性. 考虑到 $\mathrm{Al}_{2} \mathrm{O}_{3}$ 具有比 $\mathrm{ZnO}$ 更大的比表面积和更高的水热稳定 性 ${ }^{[24]}$, 因此, 本文进一步引入 $\mathrm{Al}_{2} \mathrm{O}_{3}$ 到 $\mathrm{Cu}-\mathrm{ZnO}$ 催化剂中 来提高 $\mathrm{Cu}$ 粒子的分散程度和稳定性, 通过比较三种制备 方法得到的 $\mathrm{Cu}-\mathrm{ZnO}-\mathrm{Al}_{2} \mathrm{O}_{3}$ 催化剂来考察 $\mathrm{Al}_{2} \mathrm{O}_{3}$ 的促进作 用, 同时揭示 $\mathrm{Cu}-\mathrm{ZnO}-\mathrm{Al}_{2} \mathrm{O}_{3}$ 催化剂的结构与对应 $\mathrm{Cu}-\mathrm{Zn}-\mathrm{Al}$ 碱式碳酸盐前体晶相组成之间的关联.

\section{2. 实验部分}

\section{1. 催化剂制备}

三种具有相似组成的 $\mathrm{Cu}-\mathrm{Zn}-\mathrm{Al}$ 碱式碳酸盐前体 $\left(\mathrm{Cu}: \mathrm{Zn}: \mathrm{Al}\right.$ 摩尔比为 40:40:20)分别采用均匀共沉淀法 ${ }^{[25]}$ 、 沉积-沉淀法 ${ }^{[8]}$ 和传统的共沉淀法 ${ }^{[26]}$ 制备. 其中, $\mathrm{Cu}\left(\mathrm{NO}_{3}\right)_{2} \cdot 3 \mathrm{H}_{2} \mathrm{O}, \mathrm{Zn}\left(\mathrm{NO}_{3}\right)_{2} \cdot 3 \mathrm{H}_{2} \mathrm{O}$ 和 $\mathrm{Al}\left(\mathrm{NO}_{3}\right)_{3} \cdot 9 \mathrm{H}_{2} \mathrm{O}$ 为金属 盐前体. 在均匀共沉淀方法中, 三种金属硝酸盐和尿素 按照所需比例溶解于 $100 \mathrm{~mL}$ 水溶液中; 三种金属离子
的总浓度为 $0.30 \mathrm{~mol} / \mathrm{L}$, 而尿素浓度为 $3.0 \mathrm{~mol} / \mathrm{L}$. 将溶液 加热至 $373 \mathrm{~K}$, 并保持 $3 \mathrm{~h}$, 从而得到 $\mathrm{Cu}-\mathrm{Zn}-\mathrm{Al}$ 碱式碳酸盐 沉淀. 作为对比, 同法制得 $\mathrm{Cu}-\mathrm{Zn}$ 碱式碳酸盐 $(\mathrm{Cu}: \mathrm{Zn}$ 摩尔 比 50:50). 沉积-沉淀法具有与均匀共沉淀方法相似的过 程, 除了 $\mathrm{Al}\left(\mathrm{NO}_{3}\right)_{3} \cdot 9 \mathrm{H}_{2} \mathrm{O}$ 被替换为 $\mathrm{Al}(\mathrm{OH})_{3}$ 凝胶. 其中, $\mathrm{Al}(\mathrm{OH})_{3}$ 凝胶使用相同的均匀共沉淀法制得. 在传统的 共沉淀方法中, 将含有三种金属离子的水溶液同含有 $\mathrm{NaOH}(0.34 \mathrm{~mol} / \mathrm{L})$ 和 $\mathrm{Na}_{2} \mathrm{CO}_{3}(0.060 \mathrm{~mol} / \mathrm{L})$ 的水溶液在 室温下并流滴入到 $50 \mathrm{~mL}$ 去离子水中, 之后过夜陈化. 在沉淀和陈化过程中, 溶液 $\mathrm{pH}$ 控制在9-10. 通过以上三 种方法得到的沉淀通过过滤分离, 并使用去离子水充分 洗涤至过滤液为中性, 在 $383 \mathrm{~K}$ 下干燥过夜. 之后, 催化 剂前体先后在空气气氛中于 $673 \mathrm{~K}$ 下焙烧 $4 \mathrm{~h}$, 在 $20 \%$ $\mathrm{H}_{2} / \mathrm{N}_{2}$ 中于 $623 \mathrm{~K}$ 下处理 $4 \mathrm{~h}$, 从而得到 $\mathrm{Cu}-\mathrm{ZnO}$ 以及 $\mathrm{Cu}-\mathrm{ZnO}-\mathrm{Al}_{2} \mathrm{O}_{3}$ 等催化剂. 元素分析(Vario EL)的结果表 明, 所制备的 $\mathrm{Cu}-\mathrm{ZnO}$ 催化剂中的平均 $\mathrm{Cu}: \mathrm{Zn}$ 摩尔比例为 51:49; 而通过均匀共沉淀、沉降-沉积和传统的共沉淀 方法所制备的 $\mathrm{Cu}-\mathrm{ZnO}-\mathrm{Al}_{2} \mathrm{O}_{3}$ 催化剂中的 $\mathrm{Cu}: \mathrm{Zn}: \mathrm{Al}$ 摩尔 比例分别为 39:39:22, 39:42:19和 40:39:21. 以上元素含 量组成均与实际加入值相近.

\section{2. 催化剂表征}

X射线粉末衍射谱 $\left(2 \theta=10^{\circ}-80^{\circ}\right)$ 在Rigaku D/MAX2400 衍射仪上采集. 采用 $\mathrm{Cu} K_{\alpha 1}(\lambda=0.15406 \mathrm{~nm})$ 射线, 工作电压 $40 \mathrm{kV}$, 工作电流 $100 \mathrm{~mA}$. 样品中 $\mathrm{ZnO}, \mathrm{CuO}$ 和 $\mathrm{Cu}$ 的晶体粒径通过Scherrer公式计算得到. $\mathrm{N}_{2}$ 物理吸附 在ASAP 2010吸附仪(Micromeritics)上测量. 测试前, 样 品于 $393 \mathrm{~K}$ 下真空脱气 $4 \mathrm{~h}$ (真空度低于 $0.67 \mathrm{~Pa}$ ). 催化剂 比表面积通过BET吸附模型计算得到. $\mathrm{N}_{2} \mathrm{O}$ 吸附- $\mathrm{H}_{2}$ 程 序升温还原(TPR) 实验在TP5000多用吸附仪 (天津先权) 上完成 ${ }^{[6]}$. 使用 $5 \% \mathrm{~N}_{2} \mathrm{O} / \mathrm{He}$ 混合气体 $(40 \mathrm{~mL} / \mathrm{min})$ 在 323 $\mathrm{K}$ 下处理预还原过铜基催化剂 $0.5 \mathrm{~h}$, 使样品表面的 $\mathrm{Cu}$ 原 子计量地氧化为 $\mathrm{Cu}_{2} \mathrm{O}$. 之后, 样品降至室温, 并使用 40 $\mathrm{mL} / \mathrm{min} \mathrm{He}$ 吹扫掉弱吸附的 $\mathrm{N}_{2} \mathrm{O}$. 进一步通过 $\mathrm{H}_{2}-\mathrm{TPR}$ 实 验 $\left(40 \mathrm{~mL} / \mathrm{min}, 5 \% \mathrm{H}_{2} / \mathrm{N}_{2}\right.$, 室温至 $573 \mathrm{~K}, 0.17 \mathrm{~K} / \mathrm{h}$ ) 将 $\mathrm{Cu}_{2} \mathrm{O}$ 还原为金属 $\mathrm{Cu}$. 所消耗的 $\mathrm{H}_{2}$ 通过热导检测器(TCD)定量 测量, 并据此计算 $\mathrm{Cu}$ 粒子的分散度.

\section{3. 甘油氢解反应}

在反应釜 $(100 \mathrm{~mL})$ 中加入 $50 \mathrm{~g}$ 甘油水溶液 $(10 \mathrm{wt} \%)$ 和一定量的 $\mathrm{Cu}$ 基催化剂, 并通入 $6.0 \mathrm{MPa} \mathrm{H}_{2}$. 在 800 $\mathrm{r} / \mathrm{min}$ 下将反应釜升温至 $473 \mathrm{~K}$, 进行甘油氢解反应. 反 应后的催化剂和液体产物通过常压过滤分离。液相产物 通过气相色谱(Agilent 7890A GC) 的氢离子火焰检测器 
进行分析, 色谱柱为AT-Aquawax $(30 \mathrm{~m} \times 0.25 \mathrm{~mm} \times$ $0.25 \mu \mathrm{m})$. 其中, 使用正丁醇为内标来定量甲醇和正丙 醇等低沸点化合物; 使用 $1,4-$-丁二醇为内标来定量甘 油、丙二醇和乙二醇等高沸点化合物. 气相产物, 主要包 括甲烷和 $\mathrm{CO}_{2}$, 通过Porapak-Q色谱柱进行分离, 并使用 $\mathrm{TCD}$ 定量分析. 反应产物的碳平衡为 $100 \pm 5 \%$. 与我们 此前的报道一致 ${ }^{[6,13,20]}$, 铜基催化剂的活性以催化剂表 面暴露的单位 $\mathrm{Cu}$ 原子上的甘油转化速率来表示, 而甘油 氢解产物的选择性以碳原子的选择性来表示.

\section{3. 结果与讨论}

\subsection{Cu-Zn-AI碱式碳酸盐前体的合成}

通过共沉淀法制备的 $\mathrm{Cu}-\mathrm{ZnO}$ 催化剂的活性与其碱 式碳酸盐前体有密切的关系 ${ }^{[27-29]}$. 例如, 绿铜锌矿相 $\left(\left(\mathrm{Cu}_{x} \mathrm{Zn}_{1-x}\right)_{5}(\mathrm{OH})_{6}\left(\mathrm{CO}_{3}\right)_{2}, 0<x<1\right)$ 和偏绿铜锌矿相 $\left(\left(\mathrm{Cu}_{x} \mathrm{Zn}_{1-x}\right)_{2}(\mathrm{OH})_{2} \mathrm{CO}_{3}, 0<x<1\right)$ 均由 $\mathrm{MO}_{6}$ 八面体单元 $(\mathrm{M}$ $=\mathrm{Cu}$ 和 $\mathrm{Zn}$ )连接而成, 然而在绿铜锌矿相中 $\mathrm{CuO}_{6}$ 和 $\mathrm{ZnO}_{6}$ 的分布和结合要比在偏绿铜锌矿相更为均匀和紧密 ${ }^{[30]}$. 与它们的结构差别相一致, 由绿铜锌矿相获得的 $\mathrm{Cu}-\mathrm{ZnO}$ 催化剂具有较小的 $\mathrm{Cu}$ 粒子粒径以及较强的 $\mathrm{Cu}-\mathrm{ZnO}$ 相互作用 ${ }^{[27]}$, 并在甘油氢解反应中表现出更好 的活性 ${ }^{[6]}$. 根据这一规律, $\mathrm{Al}_{2} \mathrm{O}_{3}$ 引入对 $\mathrm{Cu}-\mathrm{ZnO}$ 催化剂的 影响应该可以追溯回 $\mathrm{Al}_{2} \mathrm{O}_{3}$ 对 $\mathrm{CuO}_{6}$ 和 $\mathrm{ZnO}_{6}$ 等八面体结构 单元在对应的 $\mathrm{Cu}-\mathrm{Zn}-\mathrm{Al}$ 碱式碳酸盐前体中连接情况的 影响 ${ }^{[28,31]}$.

以尿素为沉淀剂, 采用均匀共沉淀方法来制备 $\mathrm{Cu}-\mathrm{ZnO}-\mathrm{Al}_{2} \mathrm{O}_{3}$ 催化剂 (Cu: $\mathrm{Zn}: \mathrm{Al}$ 摩尔比为 40:40:20); 作 为对比, 同法制备了 $\mathrm{Cu}-\mathrm{ZnO}$ 催化剂 $(\mathrm{Cu}: \mathrm{Zn}$ 摩尔比为 50:50), 分别标记为 CZA-HP和CZ-HP. 图 1 为两种催化 剂的碱式碳酸盐前体的XRD谱. CZ-HP的碱式碳酸盐前 体在 $13.0^{\circ}, 24.2^{\circ}$ 和 $34.3^{\circ}$ 处具有特征衍射峰, 为纯绿铜锌 矿相(JCPDS 17-074); 而CZA-HP的碱式碳酸盐前体的 衍射峰更为宽化, 并在 $14.6^{\circ}, 17.5^{\circ}$ 和 $19.4^{\circ}$ 等处出现新的 衍射峰. 其中, $14.6^{\circ}$ 和 $17.5^{\circ}$ 处的衍射峰归属于偏绿铜锌 矿相(JCPDS 36-1475), 而 $19.4^{\circ}$ 处的衍射峰可能源自一种 $\mathrm{Zn}-\mathrm{Al}$ 碱式碳酸盐 ${ }^{[32]}$. 由此可见, $\mathrm{Al}$ 源的引入降低了 $\mathrm{Cu}-\mathrm{Zn}$ 碱式碳酸盐的晶化程度, 并诱导了新的晶相结构 的生成.

由于Jahn-Teller效应所带来的 $\mathrm{Cu}^{2+}$ 离子配位环境的 畸变, $\mathrm{Al}^{3+}$ 离子并不容易与 $\mathrm{Cu}^{2+}$ 离子发生共沉淀 ${ }^{[26]}$. 因 此, 在三种离子的共沉淀过程中, 部分 $\mathrm{Al}^{3+}$ 离子与绿铜锌 矿中的 $\mathrm{Zn}^{2+}$ 离子进行交换, 从而使绿铜锌矿相的晶化程
度降低, 衍射峰相应宽化; 另一部分 $\mathrm{Al}^{3+}$ 离子则与 $\mathrm{Zn}^{2+}$ 离 子共沉淀生成一种独立的 $Z n-A 1$ 碱式碳酸盐晶相. 以上 两种影响带来了 $\mathrm{Cu}-\mathrm{Zn}$ 碱式碳酸盐中 $\mathrm{Zn}^{2+}$ 含量的偏离. 前期的研究表明 ${ }^{[6]}$, 当 $\mathrm{Cu} / \mathrm{Zn}$ 摩尔比 $\leqslant 1$ 时, 绿铜锌矿相 的生成在热力学上更为有利; 当 $\mathrm{Cu} / \mathrm{Zn}$ 摩尔比 $>1$ 时, 偏 绿铜锌矿相的生成则更为有利. 因此, 在 $\mathrm{Cu}-\mathrm{Zn}$ 碱式碳 酸盐中 $\mathrm{Zn}^{2+}$ 含量的下降导致了绿铜锌矿相向偏绿铜锌矿 相的转变, 与XRD结果一致(图1). 由此可见, 使用尿素 水解来均匀沉淀 $\mathrm{Cu}^{2+}, \mathrm{Zn}^{2+}$ 和 $\mathrm{Al}^{3+}$ 离子, 实际上得到的是 不同 $\mathrm{Cu}-\mathrm{Zn}-\mathrm{Al}$ 碱式碳酸盐的混合物.

我们进一步通过沉降-沉积和传统的共沉淀方法来 制备具有相同 $\mathrm{Cu} / \mathrm{Zn} / \mathrm{Al}$ 摩尔比例的 $\mathrm{Cu}-\mathrm{ZnO}-\mathrm{Al}_{2} \mathrm{O}_{3}$ 催化 剂(分别标记为CZA-DP和CZA-CP), 以期调变 $\mathrm{Cu}-\mathrm{Zn}-\mathrm{Al}$ 碱式碳酸盐前体的晶相组成. 在沉降-沉积方法中, 我们 利用尿素水解将 $\mathrm{Cu}^{2+}$ 和 $\mathrm{Zn}^{2+}$ 离子共沉淀到均匀分散的 $\mathrm{Al}(\mathrm{OH})_{3}$ 凝胶上 ${ }^{[8]}$. 由于在 $\mathrm{Cu}^{2+}$ 和 $\mathrm{Zn}^{2+}$ 离子共沉淀时没有 $\mathrm{Al}^{3+}$ 离子的干扰, 从而很大程度地降低了 $\mathrm{Al}$ 源引入所带 来的对 $\mathrm{Cu}-\mathrm{Zn}$ 碱式碳酸盐晶相结构的影响. 与我们的假 设一致, CZA-DP的碱式碳酸盐前体具有与CZ-HP相似 的XRD谱. 另外, 在 $14.6^{\circ}$ 和 $17.5^{\circ}$ 处表现出很微弱的偏绿 铜锌矿相的衍射峰 (图 1), 这可能源自 $\mathrm{Al}(\mathrm{OH})_{3}$ 凝胶与 $\mathrm{Cu}-\mathrm{Zn}$ 碱式碳酸盐在母液中的 Ostwald 熟化. 因此, CZA-DP碱式碳酸盐前体在组成上可以看做是无定型的 $\mathrm{Al}(\mathrm{OH})_{3}$ 与绿铜锌矿的混合物. 与此相反, 使用 $\mathrm{NaOH}$ 和 $\mathrm{Na}_{2} \mathrm{CO}_{3}$ 为沉淀剂的传统共沉淀法可以制备出具有类水 滑石晶相结构 $\left.\left((\mathrm{Cu}, \mathrm{Zn})_{1-x} \mathrm{Al} 1_{x}\right)(\mathrm{OH})_{2}\left(\mathrm{CO}_{3}\right)_{x / 2}, 0<x<1\right)$ 的 $\mathrm{Cu}-\mathrm{Zn}-\mathrm{Al}$ 碱式碳酸盐 ${ }^{[26]}$. 如图1所示, CZA-CP的碱式碳 酸盐前体的特征衍射峰为 $11.7^{\circ}, 23.4^{\circ}, 34.6^{\circ}$ 和 $38.9^{\circ}$, 是 典型的类水滑石晶相结构 (JCPDS 37-629). 单一的 $\mathrm{Cu}-\mathrm{Zn}-\mathrm{Al}$ 碱式碳酸盐结构暗示 $\mathrm{Cu}^{2+}, \mathrm{Zn}^{2+}$ 和 $\mathrm{Al}^{3+}$ 离子均匀 地分布在CZA-CP的碱式碳酸盐前体中.

综上可见, 采用不同的制备方法实现了对 $\mathrm{Cu}-\mathrm{Zn}-\mathrm{Al}$ 碱式碳酸盐前体晶相组成的调控. $\mathrm{Cu}^{2+}, \mathrm{Zn}^{2+}$ 和 $\mathrm{Al}^{3+}$ 离子 在相应碱式碳酸盐前体中的混合均匀程度的顺序为 CZA-DP $<$ CZA-HP $<$ CZA-CP. 可以预见, 三种离子在 碱式碳酸盐前体中分布均匀程度的差别将会带来 $\mathrm{Cu}-\mathrm{ZnO}-\mathrm{Al}_{2} \mathrm{O}_{3}$ 催化剂在甘油氢解反应中催化活性的不 同.

\section{2. $\mathrm{Cu}-\mathrm{ZnO}-\mathrm{Al}_{2} \mathrm{O}_{3}$ 催化剂的结构表征}

$\mathrm{Cu}-\mathrm{Zn}-\mathrm{Al}$ 碱式碳酸盐前体在 $673 \mathrm{~K}$ 下焙烧后转变为 $\mathrm{CuO}-\mathrm{ZnO}-\mathrm{Al}_{2} \mathrm{O}_{3}$ 复合氧化物. 它们的XRD谱与 $\mathrm{CuO}-\mathrm{ZnO}$ 二元复合氧化物相似(图2). $\mathrm{CuO}-\mathrm{ZnO}-\mathrm{Al}_{2} \mathrm{O}_{3}$ 复合氧化物 
上只出现单斜晶相 $\mathrm{CuO}\left(2 \theta=32.5^{\circ}, 35.7^{\circ}, 38.9^{\circ}\right.$ 和 $\left.49.0^{\circ}\right)$ 以及六方晶相 $\mathrm{ZnO}\left(2 \theta=31.8^{\circ}, 34.4^{\circ}, 36.3^{\circ}\right.$ 和 $\left.47.5^{\circ}\right)$ 对应 的特征衍射峰. $\mathrm{Al}_{2} \mathrm{O}_{3}$ 呈无定型态. 同时, $\mathrm{CuO}-\mathrm{ZnO}-$ $\mathrm{Al}_{2} \mathrm{O}_{3}$ 复合氧化物中没有氧化物之间的共生晶相出现. 与 $\mathrm{CuO}-\mathrm{ZnO}$ 二元复合氧化物相比, $\mathrm{Al}_{2} \mathrm{O}_{3}$ 的引入带来的 各晶相衍射峰的宽化, 并且其宽化随 $\mathrm{Cu}^{2+}, \mathrm{Zn}^{2+}$ 和 $\mathrm{Al}^{3+}$ 离 子在相应碱式碳酸盐前体中的混合均匀程度的增加而 更为明显 $(\mathrm{CZA}-\mathrm{DP}<\mathrm{CZA}-\mathrm{HP}<\mathrm{CZA}-\mathrm{CP})$. 衍射峰的宽 化意味着晶体粒径的减小. 与此相符, 在 CZ-HP, CZA-DP, CZA-HP和CZA-CP等复合氧化物中, $\mathrm{CuO}$ 的晶 相粒径分别为 $10.4,9.3,4.5$ 和 $3.0 \mathrm{~nm}$; 而对应的 $\mathrm{ZnO}$ 的 晶相粒径则分别 $11.8,8.4,6.0$ 和 $4.1 \mathrm{~nm}$ (表1). 以上结果暗 示, 在 $\mathrm{Cu}-\mathrm{Zn}-\mathrm{Al}$ 碱式碳酸盐前体中, $\mathrm{CuO}_{6}$ 和 $\mathrm{ZnO}_{6}$ 八面体 结构单元均被无定型的 $\mathrm{Al}_{2} \mathrm{O}_{3}$ 所分散, 导致复合氧化物 中 $\mathrm{CuO}$ 和 $\mathrm{ZnO}$ 晶体粒径的减小. 该显著影响缘于无定型 $\mathrm{Al}_{2} \mathrm{O}_{3}$ 的高比表面积和热稳定性. 如表1所示, CZ-HP对 应氧化物前体的比表面积仅为 $29 \mathrm{~m}^{2} / \mathrm{g}$, 而 CZA-DP, CZA-HP和CZA-CP对应氧化物前体的比表面积则分别 为 65,101 和 $97 \mathrm{~m}^{2} / \mathrm{g}$.

$\mathrm{CuO}-\mathrm{ZnO}-\mathrm{Al}_{2} \mathrm{O}_{3}$ 复合氧化物在 $623 \mathrm{~K}$ 用 $\mathrm{H}_{2}$ 处理 $4 \mathrm{~h}$ 后得到 Cu- $\mathrm{ZnO}-\mathrm{Al}_{2} \mathrm{O}_{3}$ 催化剂. 图3为各催化剂的XRD谱. 经过 $\mathrm{H}_{2}$ 处理后, $\mathrm{ZnO}$ 的晶相没有显著变化, 而单斜晶相 $\mathrm{CuO}$ 对应的衍射峰完全消失. 与之相应, 在 $43.4^{\circ}$ 和 $50.6^{\circ}$ 处出现新的属于立方相金属 $\mathrm{Cu}$ 的特征峰. 结果表 明, 在 $\mathrm{H}_{2}$ 处理过程中 $\mathrm{CuO}$ 被完全还原为金属 $\mathrm{Cu}$. 相比于 在复合氧化物中 $\mathrm{CuO}$ 和 $\mathrm{ZnO}$ 的晶体粒径, $\mathrm{Cu}-\mathrm{ZnO}-\mathrm{Al}_{2} \mathrm{O}_{3}$ 催化剂中金属 $\mathrm{Cu}$ 和 $\mathrm{ZnO}$ 具有更大的尺寸(表1). 其中, CZ-HP, CZA-DP, CZA-HP 和 CZA-CP的金属 $\mathrm{Cu}$ 的晶体 粒径分别为 $13.2,10.9,8.3$ 和7.4 nm; 而对应的 $\mathrm{ZnO}$ 的晶 体粒径分别为 17.0, 9.1, 6.9和4.9 nm. 另外, $\mathrm{Cu}^{2+}, \mathrm{Zn}^{2+}$ 和 $\mathrm{Al}^{3+}$ 离子分散得更为均匀的 $\mathrm{Cu}-\mathrm{Zn}-\mathrm{Al}$ 碱式碳酸盐前体 使 $\mathrm{Cu}-\mathrm{ZnO}-\mathrm{Al}_{2} \mathrm{O}_{3}$ 催化剂中的金属 $\mathrm{Cu}$ 和 $\mathrm{ZnO}$ 具有更好的 分散程度和热稳定性. 特别地, $\mathrm{Al}_{2} \mathrm{O}_{3}$ 的引入显著地提高 了 $\mathrm{ZnO}$ 的稳定性. 三种 $\mathrm{Cu}-\mathrm{ZnO}-\mathrm{Al}_{2} \mathrm{O}_{3}$ 催化剂中 $\mathrm{ZnO}$ 的晶 体粒径在 $\mathrm{H}_{2}$ 处理过程中仅略有增长 $(<1.0 \mathrm{~nm})$; 而CZ-HP 中 $\mathrm{ZnO}$ 的粒径则在此过程中从 11.8 增长到 $17.0 \mathrm{~nm}$. 不 过, 相应催化剂中 $\mathrm{Cu}$ 粒子的稳定性则没有如此明显的区 别. 这表明在 $\mathrm{Cu}-\mathrm{ZnO}-\mathrm{Al}_{2} \mathrm{O}_{3}$ 催化剂中 $\mathrm{Al}_{2} \mathrm{O}_{3}$ 与 $\mathrm{ZnO}$ 的接 触要比与金属 $\mathrm{Cu}$ 的接触更为紧密. 这与 $\mathrm{Cu}-\mathrm{Zn}-\mathrm{Al}$ 碱式 碳酸盐前体的制备过程相符. 由于 $\mathrm{Cu}^{2+}$ 的Jahn-Teller效 应, $\mathrm{Al}^{3+}$ 离子更倾向于与 $\mathrm{Zn}^{2+}$ 离子共沉淀, 而非 $\mathrm{Cu}^{2+}$ 离子.

$\mathrm{Cu}-\mathrm{ZnO}-\mathrm{Al}_{2} \mathrm{O}_{3}$ 催化剂的活性与 $\mathrm{Cu}$ 粒子的分散度和
本征的氧化还原能力相关. Cu粒子的分散度通过在 323 $\mathrm{K}$ 下 $\mathrm{N}_{2} \mathrm{O}$ 的滴定实验来测定, 并假设 $\mathrm{N}_{2} \mathrm{O}$ 与表面 $\mathrm{Cu}$ 原子 的化学计量比为 $0.5^{[33]}$. 如表 1 所示, CZ-HP, CZA-DP, CZA-HP和CZA-CP等催化剂所测得金属Cu的分散度分 别为 $9.8 \%, 13.8 \%, 15.1 \%$ 和 $20.7 \%$. Cu粒子分散度与其晶 体粒径良好的对应关系表明在 $\mathrm{Cu}-\mathrm{ZnO}-\mathrm{Al}_{2} \mathrm{O}_{3}$ 催化剂中 所有的 $\mathrm{Cu}$ 粒子均暴露在催化剂的表面. 此外, 催化剂表 面 $\mathrm{Cu}$ 粒子本征的氧化还原能力可以通过 $\mathrm{N}_{2} \mathrm{O}$ 滴定后所 形成的表面 $\mathrm{Cu}_{2} \mathrm{O}$ 物种的 $\mathrm{H}_{2}$-TPR过程来考察. 研究发 现 $^{[6]}$, 金属 $\mathrm{Cu}$ 粒子的氧化还原能力越强, 则其对应表面 $\mathrm{Cu}_{2} \mathrm{O}$ 物种的还原温度越低. 如图 4所示, $\mathrm{CZ}-\mathrm{HP}$ 上的 $\mathrm{Cu}_{2} \mathrm{O}$ 物种仅在 $436 \mathrm{~K}$ 处出现单一的还原峰. 这与 CZ-HP 碱式碳酸盐前体中单一的绿铜锌矿晶相组成相一致. 与 此相反, 在CZA-HP和CZA-DP 上的 $\mathrm{Cu}_{2} \mathrm{O}$ 物种均有两个 还原峰, 其还原温度分别为 431 和 $444 \mathrm{~K}$, 以及 443 和 454 K. 这表明这两种催化剂表面均至少含有两类金属 $\mathrm{Cu}$ 粒 子. 这些不同的Cu粒子可能源于不同的分散度或者不 同的金属-载体相互作用. 如前所述, 在均匀共沉淀和沉 降-沉积法中, Al的引入均造成了 $\mathrm{Cu}-\mathrm{Zn}$ 碱式碳酸盐前体 由绿铜锌矿相向偏绿铜锌矿相的转变. 同时, 由偏绿铜 锌矿相所得到的 $\mathrm{Cu}$ 粒子的活性要低于由绿铜锌矿相所 得到的. 因此, 我们推测在所得到的两个还原峰中, 低温 的还原峰对应于由绿铜锌矿相所得到的 $\mathrm{Cu}$ 粒子; 而高 温的还原峰则对应于由偏绿铜锌矿相所得到的 $\mathrm{Cu}$ 粒子. CZA-HP样品上高温还原峰与低温还原峰的面积比例要 高于CZA-DP样品(1.4 vs 0.67), 即CZA-HP的碱式碳酸盐 前体中的偏绿铜锌矿的含量要高于CZA-DP的碱式碳酸 盐前体, 与 XRD结果一致(图 1). 与以上两种 $\mathrm{Cu}-\mathrm{ZnO}$ $\mathrm{Al}_{2} \mathrm{O}_{3}$ 催化剂不同, $\mathrm{CZA}-\mathrm{CP}$ 上的 $\mathrm{Cu}_{2} \mathrm{O}$ 物种仅在 $447 \mathrm{~K}$ 处 出现单一的 $\mathrm{H}_{2}$ 还原峰. 同样, 这与 CZA-CP的碱式碳酸 盐前体中单一的类水滑石晶相结构相对应.

$\mathrm{Cu}-\mathrm{ZnO}-\mathrm{Al}_{2} \mathrm{O}_{3}$ 催化剂中 $\mathrm{Cu}$ 粒子的氧化还原能力主 要取决于 $\mathrm{Cu}$ 粒子的粒径以及金属 $\mathrm{Cu}$ 与 $\mathrm{ZnO}$ 之间的相互 作用. 例如, 由绿铜锌矿相所得到的 $\mathrm{Cu}$ 粒子的氧化还原 能力的关系为 CZA-DP $<$ CZ-HP $<$ CZA-HP. 一方面, CZA-DP相比于CZ-HP具有更小的 Cu粒子粒径(10.9 vs $13.2 \mathrm{~nm}$ ), 但是 $\mathrm{Al}_{2} \mathrm{O}_{3}$ 的引入削弱了 $\mathrm{Cu}$ 与 $\mathrm{ZnO}$ 间相互作用, 使得CZA-DP中Cu粒子的氧化还原能力低于CZ-HP; 另 一方面, 在CZA-HP中高的 $\mathrm{Al}_{2} \mathrm{O}_{3}$ 分散程度使 $\mathrm{Cu}$ 粒子的粒 径保持在 $8.3 \mathrm{~nm}$, 明显低于CZA-DP和CZ-HP, 从而表现 出更好的氧化还原能力. 类似地, 尽管CZA-CP中均匀分 散的 $\mathrm{Al}_{2} \mathrm{O}_{3}$ 使得其中 $\mathrm{Cu}$ 粒子粒径更小 $(7.4 \mathrm{~nm})$, 但其氧化 
还原活性要低于CZA-HP上由绿铜锌矿相所得到的 $\mathrm{Cu}$ 粒 子(447 vs $431 \mathrm{~K}$ ). 这暗示在由类水滑石 $\mathrm{Cu}-\mathrm{Zn}-\mathrm{Al}$ 碱式碳 酸盐前体所制备的 $\mathrm{Cu}-\mathrm{ZnO}-\mathrm{Al}_{2} \mathrm{O}_{3}$ 催化剂中金属 $\mathrm{Cu}$ 与 $\mathrm{ZnO}$ 之间没有强的相互作用 ${ }^{[26]}$.

上述结构表征结果表明, $\mathrm{Cu}-\mathrm{ZnO}-\mathrm{Al}_{2} \mathrm{O}_{3}$ 催化剂中 $\mathrm{Cu}$ 粒子的结构和性质与其对应的 $\mathrm{Cu}-\mathrm{Zn}-\mathrm{Al}$ 碱式碳酸盐前 体有着非常密切的关联. 这种关联为进一步调控 $\mathrm{Cu}-\mathrm{ZnO}-\mathrm{Al}_{2} \mathrm{O}_{3}$ 催化剂的活性提供了一条有效的途径. 例 如, 我们可以有目的地控制 $\mathrm{Cu}-\mathrm{Zn}-\mathrm{Al}$ 碱式碳酸盐前体中 $\mathrm{Al}^{3+}$ 的分散均匀程度.

\section{3. $\mathrm{Cu}-\mathrm{ZnO}-\mathrm{Al}_{2} \mathrm{O}_{3}$ 催化剂在甘油氢解反应中的活性、} 选择性和稳定性

$\mathrm{Cu}-\mathrm{ZnO}-\mathrm{Al}_{2} \mathrm{O}_{3}$ 催化剂在甘油氢解反应中的活性和 选择性均在动力学控制的区间内以及 $30 \%$ 的甘油转化 率下进行比较 (473 $\mathrm{K}$ 和6.0 $\mathrm{MPa} \mathrm{H}_{2}$ ). 其中, $\mathrm{Cu}-\mathrm{ZnO}-$ $\mathrm{Al}_{2} \mathrm{O}_{3}$ 催化剂的活性以表面金属 $\mathrm{Cu}$ 原子上的甘油转化速 率来表示, 即TOF. 如表2 所示, 在三种 $\mathrm{Cu}-\mathrm{ZnO}-\mathrm{Al}_{2} \mathrm{O}_{3}$ 催 化剂上甘油都高选择性地氢解为丙二醇(选择性> $90 \%$ ), 而与它们的制备方法无关. 乙二醇为主要的副产 物, 其选择性为 $6 \%-10 \%$. 此外, 还检测到微量的正丙 醇、 $\mathrm{CH}_{4}$ 以及 $\mathrm{CO}_{2}$ 的生成. 与选择性的变化不同, 三种 $\mathrm{Cu}-\mathrm{ZnO}-\mathrm{Al}_{2} \mathrm{O}_{3}$ 催化剂表现出明显不同的活性. 它们的活 性关系为 CZA-HP $\left(5.7 \mathrm{mmol}\right.$ glycerol $\left./\left(\mathrm{mol} \mathrm{Cu}_{\text {surf }} \cdot \mathrm{s}\right)\right)>$ CZ-HP (4.6 mmol glycerol/(mol/ $\left.\left./ \mathrm{Cu}_{\text {surf }} \mathrm{s}\right)\right)>$ CZA-CP $(4.4$ $\mathrm{mmol}$ glycerol/(mol Cu $\left.\left.\mathrm{u}_{\text {surf }} \mathrm{s}\right)\right)>$ CZA-DP $(2.8 \mathrm{mmol}$ glyc$\left.\mathrm{erol} /\left(\mathrm{mol} \mathrm{Cu} \mathrm{urrf}_{\mathrm{sur}} \mathrm{s}\right)\right)$. 可以看到, 通过均匀共沉淀法制备的 $\mathrm{Cu}-\mathrm{ZnO}$ 以及 $\mathrm{Cu}-\mathrm{ZnO}-\mathrm{Al}_{2} \mathrm{O}_{3}$ 催化剂比其它两种方法制备 的催化剂具有更高的本征活性.

根据我们此前对甘油氢解反应路径的研究 ${ }^{[6,20]}$, 甘 油首先在金属 $\mathrm{Cu}$ 表面脱氢为甘油醛. 甘油醛通过脱水 为丙酮醛来断裂端位的 $\mathrm{C}-\mathrm{O}$ 键, 并继续加氢得到羟基丙 酮和丙二醇(图示1). 此外, 甘油醛还可以进一步在 $\mathrm{Cu}$ 表 面上脱氢为 2-羟基丙二醛。2-羟基丙二醛通过 retro-Claisen机理断裂端位的 C-C键以得到甲酸和2-羊基 乙醛. 一方面, 甲酸在反应条件下分解为 $\mathrm{CO}_{2}$ 和 $\mathrm{H}_{2}$, 或者 加氢为甲醇. 另一方面, 2-羟基乙醛加氢得到乙二醇. 在以上反应路径中, 甘油脱氢为甘油醛很可能是反应的 速率控制步骤. 与这一推测相一致, 我们在研究 $\mathrm{Cu}-\mathrm{ZnO}$ 催化剂时发现铜基催化剂的活性与 $\mathrm{Cu}$ 粒子的氧化还原 能力有着很好的对应关系 ${ }^{[6]}$. 不过结合表 2 发现, $\mathrm{Cu}-\mathrm{ZnO}$ 和 $\mathrm{Cu}-\mathrm{ZnO}-\mathrm{Al}_{2} \mathrm{O}_{3}$ 催化剂的 $\mathrm{TOF}$ 与根据 $\mathrm{N}_{2} \mathrm{O}$ 吸附 $-\mathrm{H}_{2}$-TPR实验所揭示的表面Cu粒子的氧化还原能力并没
有严格的对应关系. 例如, CZA-HP和CZ-HP 上的 $\mathrm{Cu}_{2} \mathrm{O}$ 物种具有相似的平均还原温度 ( 438 K), 但是CZA-HP催 化剂的活性却高于CZ-HP催化剂(5.7 vs $4.6 \mathrm{mmol}$ glyc-

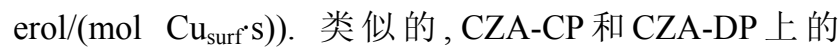
$\mathrm{Cu}_{2} \mathrm{O}$ 物种具有相似的平均还原温度 $(447 \mathrm{~K})$, 然而 CZA-CP的TOF是CZA-DP的1.6倍(4.4 vs $2.8 \mathrm{mmol}$ glyc$\left.\mathrm{erol} /\left(\mathrm{mol} \mathrm{Cu} \mathrm{surf}_{\mathrm{sur}} \mathrm{s}\right)\right)$, 与CZ-HP的TOF相近. 我们发现这种 对应关系的偏离缘于 $\mathrm{Cu}$ 粒子粒径在催化甘油氢解反应 时的增长, 因为小粒径 $\mathrm{Cu}$ 粒子的活性要明显高于大粒径 的 $^{[6,23]}$. 对于CZ-HP催化剂, Cu粒子在反应后增长至 17.0 $\mathrm{nm}$, 而 $\mathrm{Al}_{2} \mathrm{O}_{3}$ 的存在使 CZA-HP中的 $\mathrm{Cu}$ 粒子粒径在反应 后仍稳定在 $13.4 \mathrm{~nm}$. 同样地, CZA-CP和 CZA-DP中 $\mathrm{Cu}$ 粒子在反应后的粒径分别增长为 12.1 和 $17.1 \mathrm{~nm}$. 可以明 显看到, 当 $\mathrm{Cu}-\mathrm{Zn}-\mathrm{Al}$ 碱式碳酸盐前体中的 $\mathrm{Cu}^{2+}, \mathrm{Zn}^{2+}$ 和 $\mathrm{Al}^{3+}$ 离子在原子尺度上混合时, 其所对应的 $\mathrm{Cu}-\mathrm{ZnO}$ $\mathrm{Al}_{2} \mathrm{O}_{3}$ 催化剂, 如CZA-HP和CZA-CP, 具有更好的 Cu粒子 稳定性, 从而在甘油氢解反应中表现出更高的活性. 此 外, 尽管 CZA-HP和CZA-CP具有相似的 $\mathrm{Cu}$ 粒子尺寸和 稳定性, CZA-CP催化剂的活性却要低于CZA-HP. 这说 明在CZA-CP催化剂中过高的 $\mathrm{Al}_{2} \mathrm{O}_{3}$ 的分散程度在一定 程度上抑制了金属 $\mathrm{Cu}$ 与 $\mathrm{ZnO}$ 间相互作用, 造成 $\mathrm{Cu}$ 粒子活 性的降低. 由此可见, $\mathrm{Al}_{2} \mathrm{O}_{3}$ 对 $\mathrm{Cu}$ 粒子分散度和稳定性的 促进作用以及 $\mathrm{Al}_{2} \mathrm{O}_{3}$ 对 $\mathrm{Cu}-\mathrm{ZnO}$ 相互作用的削弱在优化 $\mathrm{Cu}-\mathrm{ZnO}-\mathrm{Al}_{2} \mathrm{O}_{3}$ 催化剂时需要同时考虑.

我们在 $473 \mathrm{~K}$ 和 $6.0 \mathrm{MPa} \mathrm{H}_{2}$ 的反应条件下比较了 CZ-HP 和CZA-HP催化剂在循环反应中的活性变化, 以 进一步考察 $\mathrm{Al}_{2} \mathrm{O}_{3}$ 对催化剂稳定性的促进作用. 在反应 循环时, 使用的催化剂通过过滤与液相产物分离, 在经 过充分洗涤和真空干燥后直接用于下一次反应. 如图 5 所示, 两种催化剂的活性均随反应循环数的增加而逐渐 下降, 并在四次循环后趋于稳定. 对于 CZ-HP催化剂, 其 活性在六次循环后达损失 $45 \%$ (累积反应时间 $36 \mathrm{~h}$ ). 相 比之下, CZA-HP催化剂的活性在六次循环后仅损失 $10 \%$. 元素分析的结果表明, 两种催化剂中的Cu粒子在 循环反应时均没有明显流失. 因此, 催化剂活性的下降 主要缘于 $\mathrm{Cu}$ 粒子粒径的增长. 根据 XRD测定结果, $\mathrm{CZ}-\mathrm{HP}$ 催化剂中的 $\mathrm{Cu}$ 粒子粒径经六次循环反应后增长 至45.2 nm, 明显高于CZA-HP催化剂的 $19.0 \mathrm{~nm}$. 由此可 见, $\mathrm{Al}_{2} \mathrm{O}_{3}$ 的引入不仅提高了 $\mathrm{Cu}-\mathrm{ZnO}$ 催化剂的活性, 而且 还有效地抑制了催化剂在氢解反应中的失活.

与催化剂活性的变化不同, CZ-HP和CZA-HP催化 剂的选择性在循环反应中基本保持不变(图5). 这表明 
在甘油氢解反应的选择性对 $\mathrm{Cu}$ 粒子的粒径并不敏感, 尽 管我们对这一现象的本质尚需进一步探究. 不过, 我们 注意到 $\mathrm{Al}_{2} \mathrm{O}_{3}$ 的引入使得 $\mathrm{Cu}-\mathrm{ZnO}$ 催化剂对丙二醇的选择 性从 $93.9 \%$ (CZ-HP)略降至91.6\% (CZA-HP); 与之对应, 乙二醇的选择性从 $6.0 \%$ 增长至 $8.2 \%$. 在 CZA-CP 和 CZA-DP等催化剂上也观察到类似现象。根据图示1中 的反应途径, 我们推测丙二醇与乙二醇的相对选择性主 要决定于甘油醛脱水为丙酮醛来断裂甘油端位 C-O键的 速率. 在中性的水溶液中, 甘油醛脱水主要借助氧化物 载体表面的碱性位的催化作用来完成 ${ }^{[13]}$. 如图示2所示, 甘油醛上具有酸性的 $\alpha-\mathrm{H}$ 首先被 $\mathrm{ZnO}$ 表面上具有碱性的 晶格氧所活化, 然后该 $\alpha-\mathrm{H}$ 与甘油醛的 $\beta-\mathrm{OH}$ 通过亲核反 应而生成水分子, 从而断裂甘油的端位 $\mathrm{C}-\mathrm{O}$ 键并生成丙 酮醛. 由于 $\mathrm{Al}_{2} \mathrm{O}_{3}$ 的酸性要高于 $\mathrm{ZnO}^{[34]}$, 因此 $\mathrm{Al}_{2} \mathrm{O}_{3}$ 与 $\mathrm{ZnO}$ 的混合会降低催化剂载体表面的碱性强度, 使得甘油醛 的脱水速率以及相应丙二醇的选择性发生下降。与这一 推测相符, 在三种 $\mathrm{Cu}-\mathrm{ZnO}-\mathrm{Al}_{2} \mathrm{O}_{3}$ 催化剂中具有最高 $\mathrm{Al}_{2} \mathrm{O}_{3}$ 分散度的CZA-CP催化剂表现出的丙二醇选择性 相对最低(表2).

\section{4. 结论}

通过合成 $\mathrm{Cu}^{2+}, \mathrm{Zn}^{2+}$ 和 $\mathrm{Al}^{3+}$ 离子均匀混合的 $\mathrm{Cu}-\mathrm{Zn}-\mathrm{Al}$ 碱式碳酸盐前体, 如 $\mathrm{A} 1$ 取代的绿铜锌矿, 可以有效地将 $\mathrm{Al}_{2} \mathrm{O}_{3}$ 引入到 $\mathrm{Cu}-\mathrm{ZnO}$ 催化剂中而提高它在甘油氢解反应 中的催化活性和稳定性. 在 $\mathrm{Cu}-\mathrm{ZnO}-\mathrm{Al}_{2} \mathrm{O}_{3}$ 催化剂中无定 型态的 $\mathrm{Al}_{2} \mathrm{O}_{3}$ 提高了金属 $\mathrm{Cu}$ 和 $\mathrm{ZnO}$ 的分散度, 并通过 $\mathrm{Al}_{2} \mathrm{O}_{3}$ 与 $\mathrm{ZnO}$ 之间的紧密接触提高了催化剂的热稳定性, 从而使得 $\mathrm{Cu}-\mathrm{ZnO}-\mathrm{Al}_{2} \mathrm{O}_{3}$ 催化剂具有较小的 $\mathrm{Cu}$ 粒子粒径, 相应地表现出高的氧化还原能力和催化甘油氢解活性. 不过, $\mathrm{Al}_{2} \mathrm{O}_{3}$ 与 $\mathrm{ZnO}$ 之间的紧密接触也抑制了金属 $\mathrm{Cu}$ 与 $\mathrm{ZnO}$ 之间的强相互作用, 在一定程度上抑制了 $\mathrm{Cu}$ 粒子的 活性. 此外, $\mathrm{Al}_{2} \mathrm{O}_{3}$ 的添加降低了 $\mathrm{Cu}-\mathrm{ZnO}$ 催化剂的碱性, 使得丙二醇选择性略有下降. 这缘于甘油端位C-O键的 断裂是通过碱催化的甘油醛脱水反应来实现. 以上结果 表明, 通过调变催化剂中的 $\mathrm{Al}_{2} \mathrm{O}_{3}$ 含量以及 $\mathrm{Al}_{2} \mathrm{O}_{3}$ 与金属 $\mathrm{Cu}$ 和 $\mathrm{ZnO}$ 之间的相互作用等途径可进一步提高 $\mathrm{Cu}-\mathrm{ZnO}-\mathrm{Al}_{2} \mathrm{O}_{3}$ 催化剂在甘油氢解反应中的活性、选择性 和稳定性 